\title{
6. MINERALOGY OF SILTS FROM THE BENGAL FAN ${ }^{1}$
}

\author{
Kazumi Yokoyama, ${ }^{2}$ Kazuo Amano, ${ }^{3}$ Asahiko Taira, ${ }^{4}$ and Yasuji Saito ${ }^{2}$
}

\begin{abstract}
Early Miocene to Quaternary sediments drilled from the Bengal Fan are divided into six zones by modal proportions of heavy minerals. The sediments were mostly derived from the Himalayas. Detritus from the Indian subcontinent is found sporadically in clay-rich sediments that were deposited during periods of slow sedimentation, when the deep-sea channel migrated away from the drilled sites.

The oldest sediments, ranging from 17 to about $15 \mathrm{Ma}$, were derived mostly from the Precambrian and Paleozoic sedimentary rocks of the lower Himalayas. At about $15 \mathrm{Ma}$, metamorphic terrains were eroded in the source area. Further large-scale unroofing of metamorphic rocks occurred around $11 \mathrm{Ma}$. After $10 \mathrm{Ma}$, the major constituents in the drainage basin or the drainage pattern changed a few times. Between 3.5 and $0.5 \mathrm{Ma}$, a large peridotite body was unroofed by uplift and successive erosion of the central Himalayas. At this time, the single large river that had supplied detritus to the early Bengal Fan was divided into the Indus and Ganges rivers.
\end{abstract}

\section{INTRODUCTION}

The Bengal Fan is the largest oceanic fan in the world and most of the sediments in the Fan represent erosion products of the Himalayas (e.g., Curray and Moore, 1974; Emmel and Curray, 1984). The higher part of the Himalayas is composed mainly of metamorphic rocks. The erosion of the overburden to these metamorphic rocks may have been an important factor in their uplift and eventual exposure at the Earth's surface. The sediments drilled at Sites 717-719 in the fan consist of a nearly continuous succession dating back to 17 $\mathrm{Ma}$, although there is an extremely reduced section or hiatus of nearly $1 \mathrm{~m} . \mathrm{y}$. duration near the top of the succession (Cochran, Stow, et al., 1989). These sediments represent the direct evidence for active erosion of the Himalayas, and the timing of this erosion places important constraints on their uplift history.

Only one study of heavy minerals of Bengal Fan sediments has been done on the sediments drilled previously (DSDP Leg 22 , Site 218), about $1000 \mathrm{~km}$ farther north of the drill sites studied here (Thompson, 1974). The hole bottomed in turbidite silts of the late Miocene. This study showed that pyroxene increases abruptly, and tourmaline, kyanite, and sillimanite decrease from the middle to upper Pliocene.

In this study, we analyze the modal proportions and chemical compositions of heavy and light minerals in the sediments drilled at three sites (717-719), and discuss the origin of the minerals and the drainage basins that supplied the sediments in question. Details regarding the stratigraphic sections and microfossil ages of the drilled cores are given in this volume.

\section{SAMPLE PREPARATION}

The samples are poorly consolidated and weakly cemented. They were disaggregated by soaking in water and

\footnotetext{
${ }^{1}$ Cochran, J. R., Show, D.A.V., et al., 1990. Proc. ODP, Sci. Results, 116: College Station TX, U.S.A. (Ocean Drilling Program).

2 Department of Geology, National Science Museum, Hyakunin-cho 3-231, Shinjuku-ku, Tokyo 161, Japan.

${ }^{3}$ Department of Earth Sciences, Ibaraki University, Mito 310, Japan.

${ }^{4}$ Ocean Research Institute, University of Tokyo, Minamidai, Nakano-ku, Tokyo 164, Japan.
}

then rubbing them by hand. Clay minerals and fine-grained particles were removed by washing in running tap water. The samples were subsequently dried and the heavy minerals separated from the remaining fraction by mixing with methylene iodide. The specific gravity of the liquid was reduced to 2.82 to recover composite grains and aggregates of heavy and light minerals. Some minerals such as chlorite, biotite, and carbonates are present in both heavy and light fractions. Hence, these minerals were not included in the mineral counts. As all the samples studied were restricted in volume, usually less than $7 \mathrm{~cm}^{3}$, they were not sieved. Despite this, the sample grain sizes are generally uniform, although the micaceous minerals and light minerals are usually larger than the others. The mean diameter of the heavy minerals in the different samples ranges from 0.02 to $0.06 \mathrm{~mm}$, whereas light minerals range from 0.05 to $0.2 \mathrm{~mm}$. Minerals coarser than 0.2 $\mathrm{mm}$ are exclusively micaceous.

\section{HEAVY AND LIGHT MINERALS}

The heavy and light fractions were cemented in epoxy resin and prepared for modal and chemical analyses. All the minerals were identified by means of profiles obtained by energy dispersive spectrometer (EDS). Many grains are composed of single mineral species, but composite grains and aggregates are also common. In the latter, the major constituent was measured. As the EDS profile does not distinguish between different polymorphs such as sillimanite-kyanite-andalusite, calcite-aragonite, and rutile-anatase-brookite, these minerals, when they are major minerals, were discriminated using standard optical microscopy.

More than 25 mineral species were recognized in the heavy fractions. They are fresh, probably due to their preservation under cold conditions after transportation. The most common heavy minerals are carbonates, hornblende, epidote, garnet, and biotite. Persistent accessory minerals are tourmaline, iron oxides, $\mathrm{TiO}_{2}$ polymorphs, sphene, and apatite. The number of heavy minerals counted in each sample is listed in Table 1 , as well as the relative abundance of micaceous and carbonate minerals. Selected minerals are graphically shown in Figure 1.

Major minerals in the light fraction are quartz, feldspars, and carbonates. Minerals present throughout the different sections are chlorite, biotite and muscovite. Only quartz and feldspars have been counted systematically (Table 2). Modal 


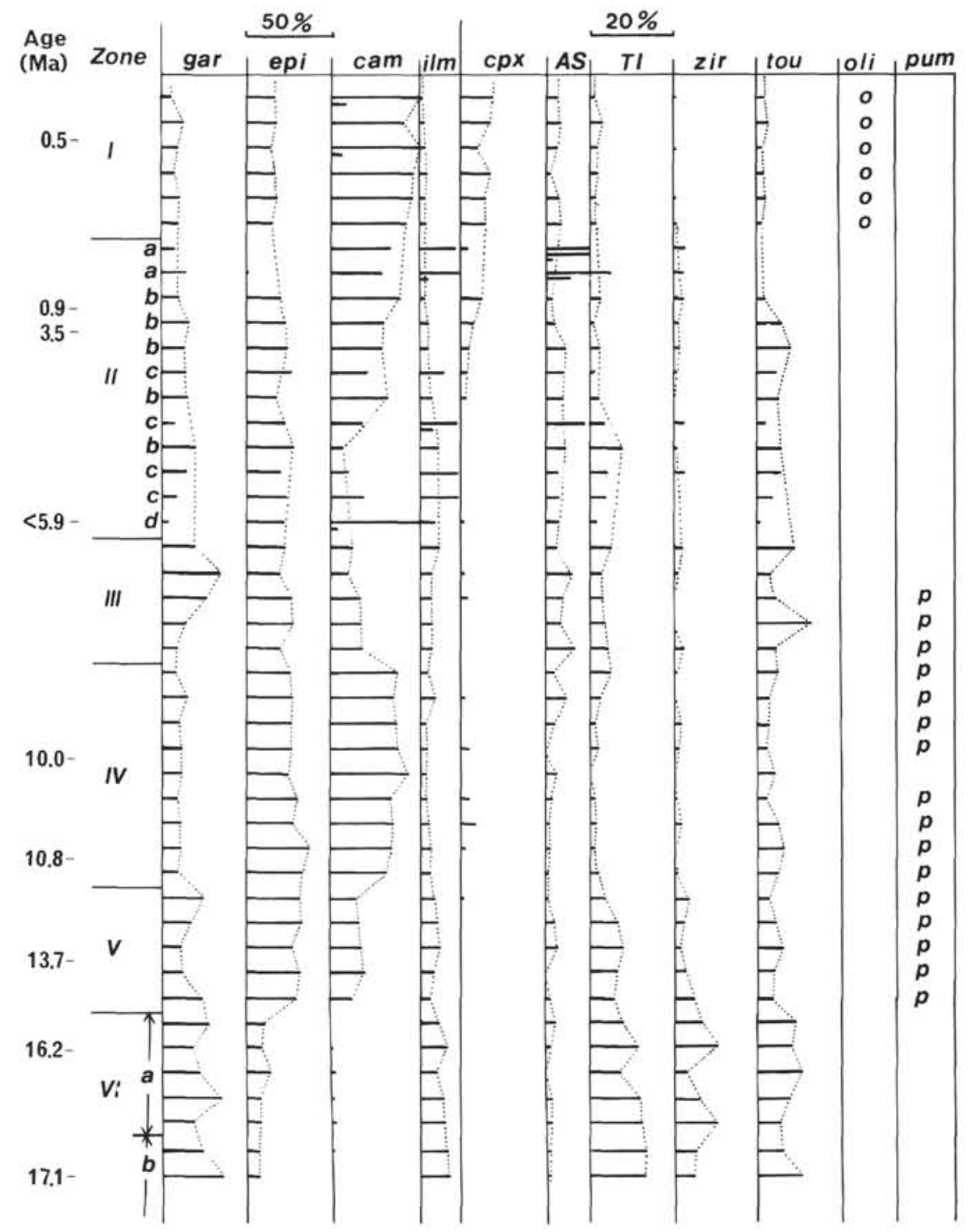

Figure 1. Modal proportions of representative heavy minerals in the early Miocene to Quaternary sediments. The samples for each zone were selected from all three holes. The samples used here and mineral abbreviations are shown in Table 1. Dotted line represents the change of modal proportions in sediments of the Himalayan origin followed in the text.

compositions of quartz, plagioclase, and K-feldspar are plotted in ternary diagrams (Fig. 2). The heavy and light minerals and their treatment in Tables 1 and 2 and Figure 1 are outlined below.

\section{Micaceous Minerals and Chlorite}

Biotite, muscovite, and chlorite are found in all of the samples. Serpentine, paragonite, margarite and talc are rare constituents. These minerals have not been counted because of their loss during washing and their different grain size. Furthermore, biotite and chlorite are commonly present in both the heavy and light fractions.

\section{Carbonate Minerals}

Dolomite is predominant among the carbonate minerals in most of the samples. It makes up more than half of the heavy minerals in the older sediments. Calcite, or aragonite, is persistent but not common except in fossiliferous samples. Rare carbonates are ankerite, siderite, and magnesite, in order of abundance. Changes of the modal proportions of the carbonate minerals except dolomite are not discussed in this paper because they may be dissolved at around the carbonate compensation depth (CCD) where all the samples were recovered, and some could be authigenic. Dolomite seems to be clastic, as dolomite grains are mostly anhedral single crystals distinct from the secondary dolomite that has an euhedral or aggregate form (von der Borch and Trueman, 1974). Furthermore, the grain size of the dolomite is roughly comparable to quartz and feldspars, and dolomite-bearing rocks are common in the Himalayas (Gansser, 1964).

\section{Garnet}

Garnet is mostly almandine-rich and commonly has inclusions of quartz, $\mathrm{TiO}_{2}$ polymorphs, and ilmenite. It locally forms composite grains with biotite or staurolite but very rarely with either amphibole or pyroxenes. Grossular and andradite are not common but occur persistently in most of the samples. 
Table 1. Modal proportions of heavy minerals at Bengal Fan sites.

\begin{tabular}{|c|c|c|c|c|c|c|c|c|c|c|c|c|c|c|c|c|c|c|c|c|c|c|}
\hline & Zone & core & gar & epi & Cam & ilm & irn & opx & $\mathrm{cpx}$ & $\mathrm{s} / \mathrm{c}$ & AS & $\mathrm{TI}$ & sph & apa & zir & tou & all & pum & oli & mic & car & others \\
\hline \multirow{23}{*}{ 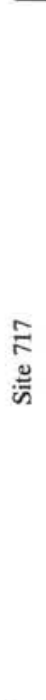 } & \multirow{6}{*}{ I } & $01^{*}$ & 31 & 90 & 323 & 9 & 6 & 2 & 40 & 9 & 18 & 6 & 15 & 18 & 2 & 10 & 1 & & 4 & A & $\mathrm{R}$ & $\mathrm{a} / \mathrm{c}(2) \operatorname{spi}(2)$ \\
\hline & & $05^{*}$ & 26 & 41 & 85 & 3 & 4 & 3 & 13 & 2 & 6 & 5 & 4 & 8 & & 5 & 5 & & 5 & C & $\mathrm{R}$ & $\operatorname{mon}(1)$ \\
\hline & & $10^{*}$ & 38 & 66 & 235 & 12 & 8 & 4 & 16 & 4 & 15 & 5 & 12 & 15 & 3 & 8 & 3 & & 1 & A & $\mathrm{R}$ & $a / c(1)$ \\
\hline & & $16^{*}$ & 12 & 28 & 83 & 5 & 8 & 2 & 11 & 1 & 1 & 2 & 5 & 7 & & 5 & 2 & & 3 & A & $\ddot{R}$ & $\operatorname{ged}(1)$ \\
\hline & & $19^{*}$ & 19 & 35 & 90 & 5 & 4 & 2 & 10 & 3 & 5 & 2 & 7 & 4 & 1 & 5 & 1 & & 1 & A & C & \\
\hline & & $20^{*}$ & 42 & 60 & 182 & 18 & 7 & 5 & 24 & 5 & 17 & 5 & 19 & 14 & 1 & 3 & 3 & & 4 & $\mathrm{~A}$ & $\mathrm{R}$ & $\operatorname{mon}(1)$ \\
\hline & \multirow{5}{*}{ II $\begin{array}{l}\mathrm{a} \\
\mathrm{a} \\
\mathrm{b} \\
\mathrm{b} \\
\mathrm{d}\end{array}$} & $22^{*}$ & 12 & & 55 & 38 & & 6 & 2 & & 50 & 4 & & 5 & 5 & & & & & $\mathrm{R}$ & A & spi(2) \\
\hline & & $23^{\circ}$ & 28 & 3 & 55 & 66 & & 4 & & & 39 & 10 & & 3 & 6 & & & & & $\mathrm{R}$ & A & spi(1) \\
\hline & & 33 & 59 & 43 & 113 & 5 & & 3 & 9 & 5 & 16 & 7 & 6 & 6 & 3 & 12 & 11 & & & $\mathrm{R}$ & $\mathrm{R}$ & $\operatorname{arf}(1)$ \\
\hline & & 36 & 31 & 45 & 125 & 3 & 7 & 1 & 4 & 5 & 4 & & 8 & 11 & 1 & 7 & 3 & & & A & R & $\mathrm{a} / \mathbf{c}(1)$ \\
\hline & & $59^{*}$ & 18 & 104 & 232 & 44 & & & 1 & 2 & 17 & 4 & 3 & 6 & 3 & 1 & & & & $\mathrm{R}$ & $\mathrm{R}$ & $\mathrm{a} / \mathrm{c}(13)$ \\
\hline & \multirow{5}{*}{ III } & $60^{\circ}$ & 69 & 69 & 44 & 34 & & & & 7 & 9 & 17 & 8 & 21 & 9 & 28 & 12 & & & A & C & $\operatorname{mon}(3) \operatorname{ged}(1)$ \\
\hline & & $62^{*}$ & 145 & 66 & 29 & 29 & 32 & 1 & 1 & 4 & 31 & 10 & 6 & 5 & 4 & 13 & 6 & & & $\mathrm{R}$ & $\mathbf{R}$ & $\mathrm{spi}(2) \operatorname{mon}(2)$ \\
\hline & & $64^{*}$ & 73 & 76 & 53 & 17 & 10 & & 4 & 5 & 13 & 7 & 3 & 12 & & 9 & 4 & 1 & & R & $\mathbf{R}$ & $\mathrm{a} / \mathrm{c}(1)$ \\
\hline & & $67^{*}$ & 14 & 28 & 18 & 6 & 2 & & & 4 & 4 & 3 & 6 & 5 & & 8 & 4 & 1 & & A & $\mathbf{R}$ & \\
\hline & & $69^{*}$ & 9 & 18 & 17 & 6 & 9 & & & 2 & 6 & 4 & 5 & 9 & 2 & 4 & 5 & 1 & & A & A & \\
\hline & \multirow{7}{*}{ IV } & 71 & 19 & 43 & 50 & 7 & 2 & & 1 & 1 & 1 & 3 & 2 & 6 & & 5 & 1 & 3 & & A & A & \\
\hline & & 76 & 26 & 72 & 66 & 8 & 6 & & & 7 & 9 & 5 & 5 & 6 & & 7 & 3 & & & $\mathrm{C}$ & $\mathrm{R}$ & spi(1) \\
\hline & & 77 & 36 & 44 & 50 & 14 & 1 & & 1 & 6 & 3 & 9 & 7 & 7 & & 12 & & 1 & & A & $\mathrm{R}$ & $\operatorname{mon}(1)$ \\
\hline & & 82 & 31 & 63 & 68 & 8 & 10 & & 2 & 1 & 4 & 5 & 4 & 3 & 3 & 8 & & 1 & & $\mathrm{C}$ & $\mathrm{R}$ & $\mathrm{a} / \mathrm{c}(2)$ \\
\hline & & 86 & 30 & 74 & 54 & 17 & 9 & & 2 & 2 & 4 & 6 & 8 & 5 & 2 & 3 & 1 & 3 & & $\mathrm{R}$ & C & $\operatorname{mon}(1)$ \\
\hline & & 90 & 22 & 59 & 80 & 10 & 3 & & & 2 & & 5 & 3 & 7 & & 2 & 3 & 2 & & $\vec{R}$ & $\mathbf{R}$ & $\mathrm{a} / \mathrm{c}(1) \mathrm{spi}(1) \operatorname{mon}(1)$ \\
\hline & & 91 & 44 & 88 & 52 & 17 & 5 & & & 1 & 5 & 7 & 12 & 8 & & 22 & 2 & 7 & & C & $\mathbf{R}$ & \\
\hline & & 01 & 12 & 32 & 95 & 2 & 2 & 2 & 8 & 4 & 1 & 1 & 6 & 9 & & 4 & 1 & & 1 & A & $\mathrm{R}$ & $\operatorname{pig}(1)$ \\
\hline & I & 04 & 24 & 49 & 161 & 6 & 4 & 5 & 19 & 2 & 12 & & 8 & 7 & & 7 & 2 & & 3 & A & $\mathbf{R}$ & $\mathrm{a} / \mathrm{c}(1) \operatorname{spi}(1)$ \\
\hline & & 11 & 34 & 38 & 86 & 4 & 8 & 2 & 11 & 1 & 6 & 1 & 9 & 8 & 3 & 4 & 5 & & 1 & $\mathrm{R}$ & $\mathbf{R}$ & pig(1) \\
\hline & II b & 18 & 26 & 37 & 52 & 3 & 6 & 2 & 11 & 1 & 14 & 1 & 4 & & 2 & 3 & 2 & & & $\mathrm{C}$ & $\mathrm{R}$ & $\mathrm{a} / \mathrm{c}(1)$ \\
\hline & & 20 & 54 & 42 & 35 & 8 & 4 & & & 5 & 11 & 4 & 8 & 5 & 2 & 15 & 2 & & & $\mathrm{C}$ & $\mathbf{R}$ & \\
\hline & III & 24 & 33 & 53 & 24 & 11 & 10 & 1 & 2 & 7 & 13 & 4 & 6 & 7 & & 15 & 2 & 1 & & A & $\mathbf{R}$ & spi(1) mon(1) \\
\hline & & $27^{*}$ & 16 & 48 & 77 & 7 & 10 & & & & 5 & 9 & 7 & 9 & 1 & 10 & & 2 & & A & C & \\
\hline & & $31^{*}$ & 31 & 55 & 74 & 14 & 10 & & 1 & 2 & 10 & 5 & 6 & 5 & & 6 & & 1 & & $\mathrm{C}$ & $\mathbf{R}$ & \\
\hline & & $33^{*}$ & 10 & 45 & 71 & 8 & 8 & & & 2 & 5 & 3 & 5 & 9 & 2 & 5 & 2 & 1 & & A & $\mathrm{R}$ & $\operatorname{arf}(1) \operatorname{spi}(1)$ \\
\hline & & $38^{*}$ & 19 & 47 & 75 & 8 & 6 & & 3 & 2 & & 3 & 4 & 9 & 1 & 4 & 1 & 1 & & A & $\ddot{R}$ & spi(1) \\
\hline & IV & $44^{*}$ & 19 & 39 & 73 & 4 & 8 & 3 & & & 4 & & 2 & 5 & & 6 & 2 & & & C & $\mathrm{R}$ & spi(1) \\
\hline & & $48^{*}$ & 32 & 105 & 125 & 17 & 15 & 3 & 7 & 5 & 7 & 7 & 7 & 7 & 1 & 10 & 2 & 4 & & C & $\mathbf{R}$ & $a / c(1)$ \\
\hline & & $52^{*}$ & 15 & 39 & 52 & 6 & 6 & 1 & 5 & 3 & 1 & 2 & 3 & 5 & 2 & 7 & 1 & 1 & & A & A & \\
\hline$\stackrel{\infty}{=}$ & & $56^{*}$ & 18 & 65 & 64 & 10 & 6 & & 1 & 2 & 1 & 2 & 2 & 2 & & 13 & 3 & 2 & & $\mathrm{R}$ & C & \\
\hline$\cong$ & & $62^{*}$ & 28 & 110 & 94 & 19 & 15 & & & 5 & 1 & 9 & 8 & 11 & 1 & 12 & 3 & 2 & & R & A & $\mathrm{a} / \mathrm{c}(2) \operatorname{mon}(1)$ \\
\hline & & $65^{*}$ & 43 & 58 & 25 & 17 & 15 & & 1 & 1 & 1 & 6 & 6 & 4 & 6 & 5 & 2 & 4 & & $\mathbf{R}$ & A & $\mathrm{a} / \mathrm{c}(1)$ \\
\hline & & $69^{*}$ & 57 & 88 & 48 & 42 & 28 & 2 & 1 & 3 & 5 & 24 & 19 & 11 & 9 & 14 & 6 & 5 & & $\mathrm{R}$ & C & $\operatorname{spi}(2) \mathrm{mon}(1)$ \\
\hline & V & $71^{*}$ & 17 & 44 & 27 & 18 & 7 & & & 1 & 5 & 12 & 5 & 6 & 2 & 9 & 4 & 4 & & $\mathrm{R}$ & A & $\operatorname{acm}(1)$ \\
\hline & & $73^{*}$ & 9 & 24 & 14 & 6 & 7 & & & & & 5 & 2 & 7 & 2 & 3 & & 1 & & $\mathrm{C}$ & A & \\
\hline & & $77^{*}$ & 72 & 99 & 34 & 25 & 32 & & 1 & 4 & 3 & 22 & 13 & 10 & 15 & 15 & 3 & 3 & & $\mathbf{R}$ & A & spi(3) \\
\hline & 4 & $79^{*}$ & 58 & 22 & & 24 & 32 & & & 2 & 5 & 16 & 3 & 15 & 14 & 19 & 4 & & & $\mathrm{C}$ & A & $\operatorname{mon}(1)$ \\
\hline & & $81^{*}$ & 43 & 24 & 3 & 54 & 20 & & & 6 & 4 & 32 & 9 & 22 & 30 & 21 & 6 & & & A & A & spi(1) mon(1) \\
\hline & a & $86^{*}$ & 31 & 18 & 2 & 12 & 16 & & & 4 & & 10 & 4 & 18 & 4 & 14 & 6 & & & $\mathbf{R}$ & A & \\
\hline & 1 & $88^{*}$ & 76 & 27 & 3 & 48 & 70 & & & 6 & 3 & 41 & 12 & 23 & 24 & 28 & 8 & & & $\mathbf{R}$ & A & \\
\hline & VI $\downarrow$ & $93^{*}$ & 28 & 13 & 3 & 22 & 20 & & & 1 & 2 & 19 & 3 & 9 & 15 & 8 & 1 & & & $\mathrm{R}$ & A & \\
\hline & $A$ & 97 & 9 & 3 & & 8 & 2 & & & & & 5 & & 1 & 1 & 1 & 1 & & & R & A & $\operatorname{mon}(1)$ \\
\hline & b & $98^{\circ}$ & 65 & 18 & 3 & 57 & 35 & & & & 1 & 37 & 6 & 30 & 15 & 13 & 4 & & & $\mathbf{R}$ & A & \\
\hline & I & $\mathrm{E} 2 *$ & 77 & 23 & & 84 & 38 & & & 6 & 3 & 51 & 7 & 28 & 20 & 34 & 8 & & & A & A & spi(1) mon(1) \\
\hline & I & 15 & 31 & 30 & 79 & & 1 & 1 & 13 & 2 & 8 & 2 & 7 & 5 & & 5 & 1 & & 3 & $\mathrm{C}$ & $\mathbf{R}$ & $\mathrm{a} / \mathrm{c}(3) \operatorname{mon}(1)$ \\
\hline & a & 16 & 3 & 1 & 21 & 5 & & 1 & 1 & & 8 & & & & 1 & & & & & $\mathbf{R}$ & A & spi(1) \\
\hline & c & 17 & & 2 & 9 & 12 & & & & & 4 & 1 & & 4 & & & & & & $\mathrm{C}$ & A & \\
\hline & b & $23^{*}$ & 9 & 18 & 36 & 2 & 3 & & 4 & & 1 & 2 & 5 & 8 & 2 & 1 & 2 & & & C & $\mathrm{R}$ & $\mathrm{a} / \mathrm{c}(1)$ \\
\hline & b & $24^{*}$ & 74 & 86 & 129 & 15 & 27 & 1 & 8 & 4 & 15 & 4 & 15 & 9 & 5 & 19 & 7 & & & $\mathrm{C}$ & $\mathrm{R}$ & $a / c(1)$ \\
\hline & b & $25^{*}$ & 26 & 49 & 61 & 8 & 5 & 1 & 2 & 5 & 9 & 5 & 9 & 2 & 2 & 16 & 4 & & & A & $\mathrm{R}$ & $\operatorname{pev}(1)$ \\
\hline$\vec{n}$ & II $\mathrm{c}$ & $26^{*}$ & 30 & 55 & 47 & 31 & 3 & & 3 & 5 & 10 & 2 & 8 & 6 & 2 & 9 & 7 & & & $\mathrm{C}$ & $\mathrm{R}$ & \\
\hline$\cong$ & b & $27^{*}$ & 35 & 40 & 81 & 14 & 7 & & 2 & 7 & 11 & 5 & 9 & 12 & & 12 & 5 & & & $\mathrm{R}$ & $\mathrm{R}$ & \\
\hline के & c & $28^{*}$ & 12 & 48 & 40 & 74 & 3 & & & & 21 & 7 & 5 & 7 & 3 & 3 & 2 & & & $\mathrm{C}$ & R & $a / c(1) \operatorname{arf}(1)$ \\
\hline & b & $32^{*}$ & 39 & 56 & 14 & 24 & 4 & & & 3 & 10 & 16 & 10 & 17 & 2 & 11 & 8 & & & $\mathbf{R}$ & $\mathrm{C}$ & \\
\hline & c & $33^{*}$ & 60 & 79 & 45 & 96 & 26 & & & 3 & 13 & 19 & 29 & 28 & 11 & 23 & 7 & & & $\mathrm{C}$ & A & $\mathrm{a} / \mathrm{c}(1) \operatorname{mon}(1) \mathrm{spi}(1)$ \\
\hline & c & $34^{*}$ & 6 & 17 & 13 & 17 & 4 & & & & 2 & 3 & 4 & 6 & & 3 & & & & $\mathrm{C}$ & C & \\
\hline & & 39 & 48 & 48 & 20 & 16 & 8 & & & 6 & 5 & 4 & 6 & 8 & 6 & 17 & 5 & 1 & & $\mathbf{R}$ & $\mathbf{R}$ & $\operatorname{mon}(1)$ \\
\hline & III & 40 & 59 & 53 & 13 & 7 & 7 & & 1 & 9 & 11 & 7 & 13 & 2 & 2 & 23 & 2 & 1 & & C & $\mathrm{R}$ & $\operatorname{mon}(1)$ \\
\hline
\end{tabular}

*Used in Figure 1. Mineral abbreviations: gar $=$ garnet, epi $=$ epidote group minerals, cam $=$ calcic amphibole, ilm $=$ ilmenite, iron=magnetite and hematite, opx $=$ orthopyroxene, $\mathrm{cpx}=$ calcic pyroxene, $\mathrm{s} / \mathrm{c}=$ staurolite and chloritoid, $\mathrm{AS}=\mathrm{Al}_{2} \mathrm{O}_{5}$ polymorphs, $\mathrm{TI}=\mathrm{TiO}_{2}$ polymorphs, $\mathrm{sph}=\mathrm{sphene}$, apa $=$ apatite, zir $=$ zircon, all $=$ allanite, pum $=$ pumpellyite, oli $=$ olivine, mic $=$ micaceous minerals, car $=$ carbonaceous minerals, $\mathrm{a} / \mathrm{c}=$ anthophyllite and cummingtonite, spi $=$ spinel, mon $=$ monazite, ged $=$ sodium gedrite, arf $=$ arfvedsonite, pig $=$ pigeonite, acm $=$ acmite, pev $=$ perovskite. $\mathrm{A}=$ abundant . $\mathrm{C}=$ common. $\mathrm{R}=$ rare. 
Table 2. Modal proportions of light minerals and details of sample localities.

\begin{tabular}{|c|c|c|c|c|c|c|c|}
\hline Zone & core & sec & interval $(\mathrm{cm})$ & $q z$ & $\mathrm{pl}$ & $a b$ & kf \\
\hline \multirow{4}{*}{ I } & 01 & 03 & $64-66$ & 92 & 24 & 18 & 19 \\
\hline & 03 & 03 & $118-120$ & 111 & 21 & 6 & 27 \\
\hline & 04 & $\mathrm{CC}$ & $13-15$ & 153 & 27 & 11 & 23 \\
\hline & 11 & $\mathrm{CC}$ & $15-17$ & 157 & 35 & 5 & 19 \\
\hline \multirow{4}{*}{ II } & 14 & 06 & $26-28$ & 70 & 52 & 5 & 26 \\
\hline & 15 & 02 & $86-88$ & 212 & 58 & 10 & 21 \\
\hline & 16 & 04 & $120-122$ & 123 & 16 & 12 & 7 \\
\hline & 18 & $\mathrm{CC}$ & & 86 & 22 & 3 & 18 \\
\hline \multirow[b]{2}{*}{ III } & 20 & $\mathrm{CC}$ & $32-34$ & 156 & 19 & 11 & 17 \\
\hline & 24 & 02 & $29-31$ & 155 & 12 & 22 & 13 \\
\hline \multirow{9}{*}{ IV } & 27 & 01 & $103-105$ & 75 & 17 & 8 & 21 \\
\hline & 31 & $\mathrm{CC}$ & & 174 & 34 & 13 & 16 \\
\hline & 33 & 01 & $20-22$ & 155 & 23 & 15 & 33 \\
\hline & 38 & 01 & $63-65$ & 114 & 17 & 6 & 15 \\
\hline & 44 & 01 & $20-22$ & 169 & 24 & 14 & 17 \\
\hline & 48 & 01 & $41-43$ & 155 & 26 & 21 & 22 \\
\hline & 52 & 01 & $19-21$ & 108 & 18 & 13 & 13 \\
\hline & 56 & 01 & $73-75$ & 151 & 18 & 13 & 15 \\
\hline & 62 & 02 & $96-98$ & 103 & 19 & 11 & 21 \\
\hline \multirow{5}{*}{ V } & 65 & 05 & $84-86$ & 314 & 12 & 13 & 24 \\
\hline & 69 & 02 & $68-70$ & 156 & 9 & 10 & 17 \\
\hline & 71 & 05 & $48-50$ & 181 & 4 & 8 & 9 \\
\hline & 73 & 02 & $98-100$ & 158 & 13 & 12 & 13 \\
\hline & 77 & $\mathrm{CC}$ & & 269 & 12 & 13 & 26 \\
\hline \multirow[t]{4}{*}{ 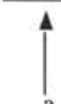 } & 78 & 05 & $130-132$ & 155 & 5 & 22 & 20 \\
\hline & 79 & $\mathrm{CC}$ & $16-18$ & 271 & 7 & 9 & 26 \\
\hline & 81 & $\mathrm{CC}$ & & 271 & 7 & 33 & 27 \\
\hline & 86 & 01 & $131-133$ & 151 & 4 & 17 & 17 \\
\hline \multirow[b]{2}{*}{ VI $\downarrow$} & 88 & 04 & $37-39$ & 197 & 1 & 7 & 14 \\
\hline & 93 & 01 & $12-14$ & 150 & 0 & 11 & 12 \\
\hline \multirow[t]{4}{*}{4} & 97 & 01 & $24-26$ & 177 & 1 & 6 & 7 \\
\hline & 98 & $\mathrm{CC}$ & $11-13$ & 267 & 4 & 15 & 22 \\
\hline & E2 & 03 & $110-112$ & 252 & 6 & 18 & 21 \\
\hline & E3 & 01 & $38-40$ & 254 & 7 & 25 & 34 \\
\hline
\end{tabular}

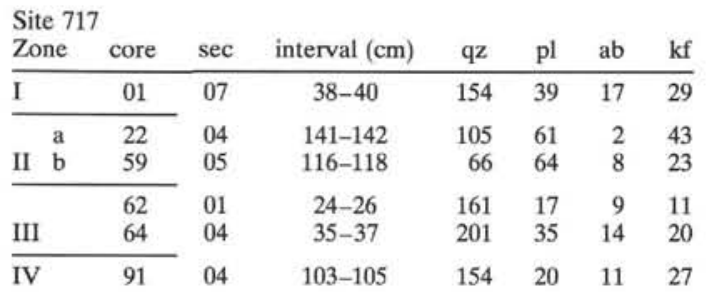

\begin{tabular}{|c|c|c|c|c|c|c|c|c|}
\hline & $\begin{array}{l}\text { e } 719 \\
\text { ne }\end{array}$ & core & sec & interval $(\mathrm{cm})$ & $q z$ & $\mathrm{pl}$ & $a b$ & $\mathrm{kf}$ \\
\hline \multirow{6}{*}{ II } & $\mathbf{a}$ & 16 & $\mathrm{CC}$ & $0-1$ & 101 & 48 & 1 & 42 \\
\hline & c & 17 & 06 & $89-91$ & 94 & 58 & 7 & 27 \\
\hline & c & 26 & $\mathrm{CC}$ & $0-1$ & 171 & 29 & 7 & 25 \\
\hline & c & 28 & 02 & $92-94$ & 121 & 29 & 15 & 26 \\
\hline & b & 32 & $\mathrm{CC}$ & $0-1$ & 216 & 23 & 21 & 30 \\
\hline & c & 33 & $\mathrm{CC}$ & $10-12$ & 156 & 33 & 19 & 9 \\
\hline
\end{tabular}

\section{Epidote-group Minerals and Pumpellyite}

Epidote-group minerals are present mainly as single crystals but commonly occur as composite grains and aggregates. Pumpellyite is present mostly as a breakdown product of plagioclase.

\section{Amphibole}

The most common amphibole is bluish to brownish green hornblende, but actinolite-tremolite is not rare. As the composition from hornblende to actinolite-tremolite is almost continuous and the mineral species cannot be simply divided using the EDS profile, they are treated together in Table 1 and Figure 1. Grains of sodic amphibole have an arfvedsonite composition. Riebeckite-glaucophane series
Table 2 (continued).

\begin{tabular}{|c|c|c|c|c|c|}
\hline \multicolumn{6}{|c|}{ Samples used only for heavy minerals } \\
\hline \multicolumn{2}{|c|}{ Site 717} & interval $(\mathrm{cm})$ & \multicolumn{2}{|l|}{ Site 718} & interval $(\mathrm{cm})$ \\
\hline 05 & 02 & $34-36$ & 27 & $\mathrm{CC}$ & \\
\hline 10 & 01 & $142-144$ & 33 & $\mathrm{CC}$ & \\
\hline 16 & 01 & $107-109$ & & & \\
\hline 19 & 01 & 104-106 & \multicolumn{2}{|c|}{ Site 719} & \\
\hline 20 & 01 & $32-34$ & core & $\sec$ & interval $(\mathrm{cm})$ \\
\hline 23 & 02 & $146-148$ & 15 & $\mathrm{CC}$ & $0-1$ \\
\hline 33 & $\mathrm{CC}$ & $33-35$ & 23 & $\mathrm{CC}$ & $29-31$ \\
\hline 36 & 07 & $8-10$ & 24 & $\mathrm{CC}$ & $0-1$ \\
\hline 60 & $\mathrm{CC}$ & $14-16$ & 25 & $\mathrm{CC}$ & $0-1$ \\
\hline 67 & 02 & $55-57$ & 27 & $\mathrm{CC}$ & $0-1$ \\
\hline 69 & $\mathrm{CC}$ & $18-20$ & 34 & 02 & $74-76$ \\
\hline 71 & 04 & $96-98$ & 39 & $\mathrm{CC}$ & $0-1$ \\
\hline 76 & 04 & $123-125$ & 40 & $\mathrm{CC}$ & $0-1$ \\
\hline 77 & 01 & $77-79$ & & & \\
\hline 82 & 01 & $18-20$ & & & \\
\hline 86 & 01 & $23-25$ & & & \\
\hline 90 & 01 & $10-12$ & & & \\
\hline
\end{tabular}

Mineral abbrevations: $\mathrm{qz}=$ quartz, $\mathrm{pl}=$ calcic plagioclase $\left(>\mathrm{An}_{10}\right), \mathrm{ab}=$ albite and $\mathrm{kf}=\mathrm{K}$-feldspar.

minerals, previously reported from the Bengal Fan (Thompson, 1974), were not observed. Calcium-poor amphibole is represented by anthophyllite, cummingtonite and rarely sodium gedrite. Cummingtonite is rarely associated with hypersthene.

\section{Aluminous Silicates}

$\mathrm{Al}_{2} \mathrm{SiO}_{5}$ polymorphs are present throughout the sediments, but in most samples they are too rare to be identified. In two samples where identification was possible, the grains were sillimanite. Staurolite and chloritoid occur in the oldest sediments, but are rare constituents. As the modal proportions of both the minerals do not correlate with depth or age, they are treated together in Table 1.

\section{Oxides}

There are many species of the iron-rich oxides. As magnetite and hematite have variable $\mathrm{TiO}_{2}$ contents, they cannot be accurately distinguished and are treated together in Table 1. Ilmenite commonly has inclusions of quartz, locally associated with sphene and $\mathrm{TiO}_{2}$ polymorphs. Goethite is persistent but was not counted because it could be either detrital or diagenetic. $\mathrm{TiO}_{2}$ polymorphs and zircon are present throughout the sequence and are common in the older sediments. $\mathrm{Fe}_{2} \mathrm{O}_{3}$-poor spinel and perovskite are rare. The spinels include chromite, chromian spinel, $\mathrm{Cr}$-free spinel and zincian spinel in order of abundance.

\section{Pyrite}

Pyrite is persistent in the heavy fraction. It is common in fossiliferous samples. Many pyrite grains have a well-developed framboidal texture, showing the replacement of microfossils. Although there are some anhedral to subhedral pyrites of possible detrital origin, such pyrites were not counted because of the wide variety of possible sources, precluding their use in provenance determinations.

\section{Other Minerals}

Other minerals observed were tourmaline, pyroxenes, olivine, sphene, allanite, monazite, and apatite in the heavy fraction, and scapolite and cordierite in the light fraction. The most commonly observed pyroxenes are diopside, salite, augite, hypersthene, and enstatite, whereas pigeonite, hedenbergite, and aegirine are rare. 


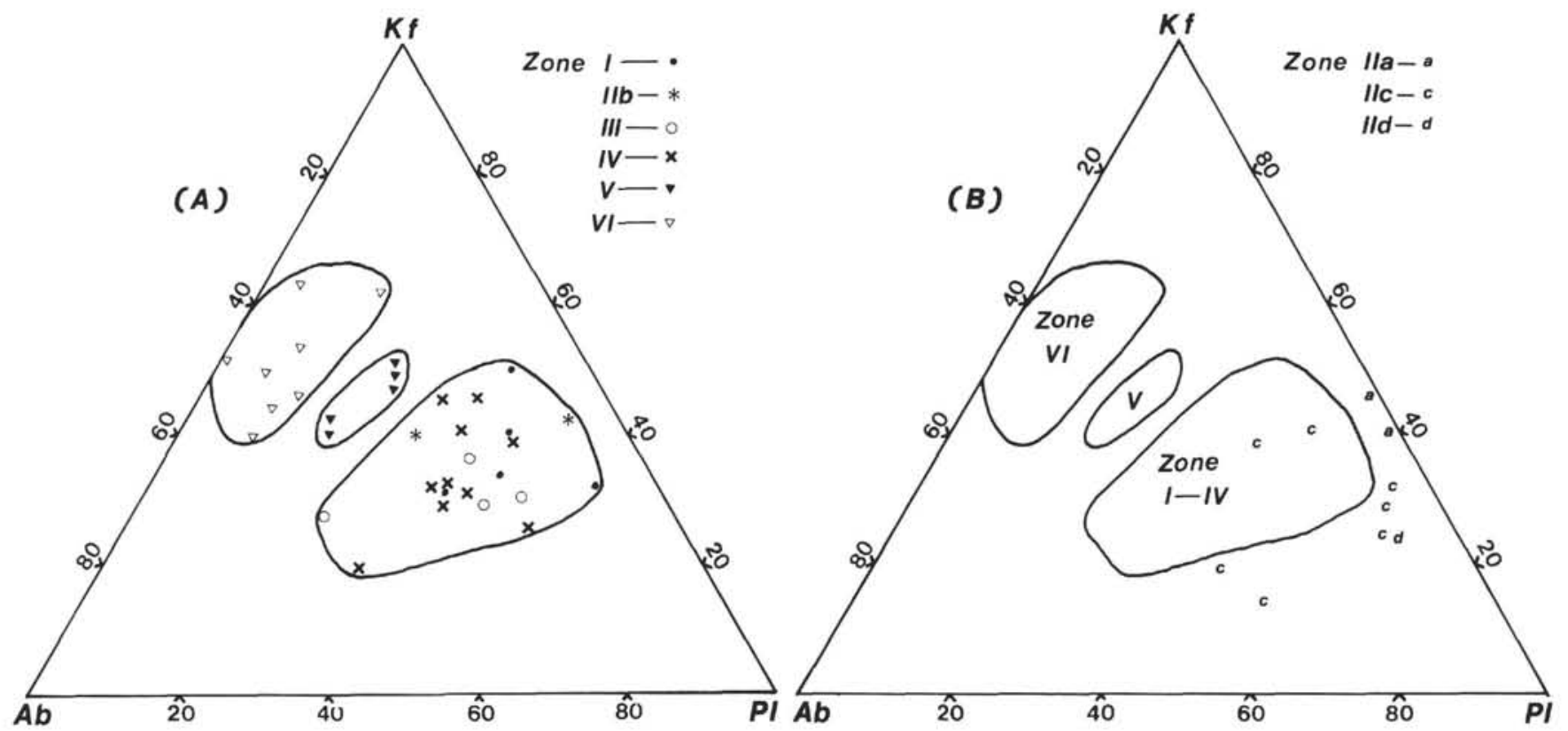

Figure 2. Modal proportions of light minerals plotted in ternary diagrams of quartz-plagioclase-K-feldspar. A. Sediments from the Himalayas. B. Sediments from the Indian subcontinent.

\section{ZONE DIVISIONS}

Based on the modal proportions of the heavy minerals from Sites 717-719, the early Miocene to Quaternary sediments have been divided into six zones as shown in Tables 1 and 2 and Figure 1. As sample recovery in each zone varied from site to site, the samples for each zone are selected from the three sites and the modal proportions of representative minerals are combined with the samples in Figure 1 . The heavy mineral assemblages and modal proportions do not differ much throughout each zone, indicating that the sediments were derived from the same source for the duration of each zone. Zones I to IV are present in at least two sites. At the zone boundaries, clay layers over $5 \mathrm{~m}$ in thickness are usually present (see stratigraphic section, this volume). As microfossil ages are only obtained sporadically (this volume and Fig. 1), the durations of each zone and clay layer at the zone boundary have not been confirmed. The six zones are defined as follows.

\section{Zone VI}

This is the oldest zone and was drilled only at Site 718. The lower part of this zone is early Miocene. Carbonate minerals, especially dolomite, are predominant, accounting for half of the heavy minerals. Other common heavy minerals are zircon, iron oxides, garnet, ilmenite, tourmaline, epidote, and $\mathrm{TiO}_{2}$ polymorphs. Amphibole is scarce. This zone is subdivided into VIa and VIb by the modal proportion of zoisite as discussed later.

\section{Zone V}

Calcic amphibole and pumpellyite appear persistently from the base of this zone upward. Epidote-group minerals comprise around $40 \%$, more than twice the abundance in Zone VI. Ilmenite, iron oxides, zircon, and tourmaline are less common than in Zone VI.

\section{Zone IV}

The mineral assemblage in this zone is similar to that in Zone $\mathrm{V}$, but the modal proportion of amphibole increases abruptly to around $40 \%$. Carbonate minerals, $\mathrm{TiO}_{2}$ polymorphs and zircon become less abundant. Pyroxenes appear sporadically within this zone.

\section{Zone III}

The modal proportion of amphibole decreases abruptly between Zones IV and III, typically being less than $20 \%$. Pumpellyite disappears within this zone. Tourmaline and $\mathrm{TiO}_{2}$ polymorphs are more common than in Zone IV.

\section{Zone II}

This zone consists mostly of clay-rich sediments sporadically intercalated with silts. Fossiliferous silt and clay are common. The silt and silty clay have various modal proportions in heavy minerals and are classified into four types from IIa to IId based on modal proportions and chemical compositions of minerals. IIa sediments are characterized by abundance of sillimanite and almost complete absence of epidote. Sediments in IIc and IId are ilmenite-rich and anthophyllitecummingtonite-rich, respectively. Zones IIa, IIc, and IId differ in modal proportions and chemical compositions from Zones III, and I, whereas IIb sediments have strong affinities in mineralogical composition with Zones VI to I sediments as discussed later.

\section{Zone I}

Olivine is present throughout this zone, and is associated with large amounts of calcic amphibole, comprising around half of the heavy mineral suite. Clinopyroxene comprises $4 \%-8 \%$ in this zone. It is noteworthy that modal proportion of the major heavy minerals in this zone are similar to those in Zone IV.

\section{Light Minerals}

The modal proportions of light minerals do not change as markedly as those of the heavy minerals. Quartz is higher in the older sediments (Zones VI-V) than in the younger sediments (Zones IV-I, Fig. 2A), whereas plagioclase $\left(>A_{10}\right)$ increases upward (Fig. 3A). The light mineral proportions in Zones IIa, IIc, and IId do not generally fit with these trends, whereas those in Zone IIb are more in line (Figs. 2B and 3B). 


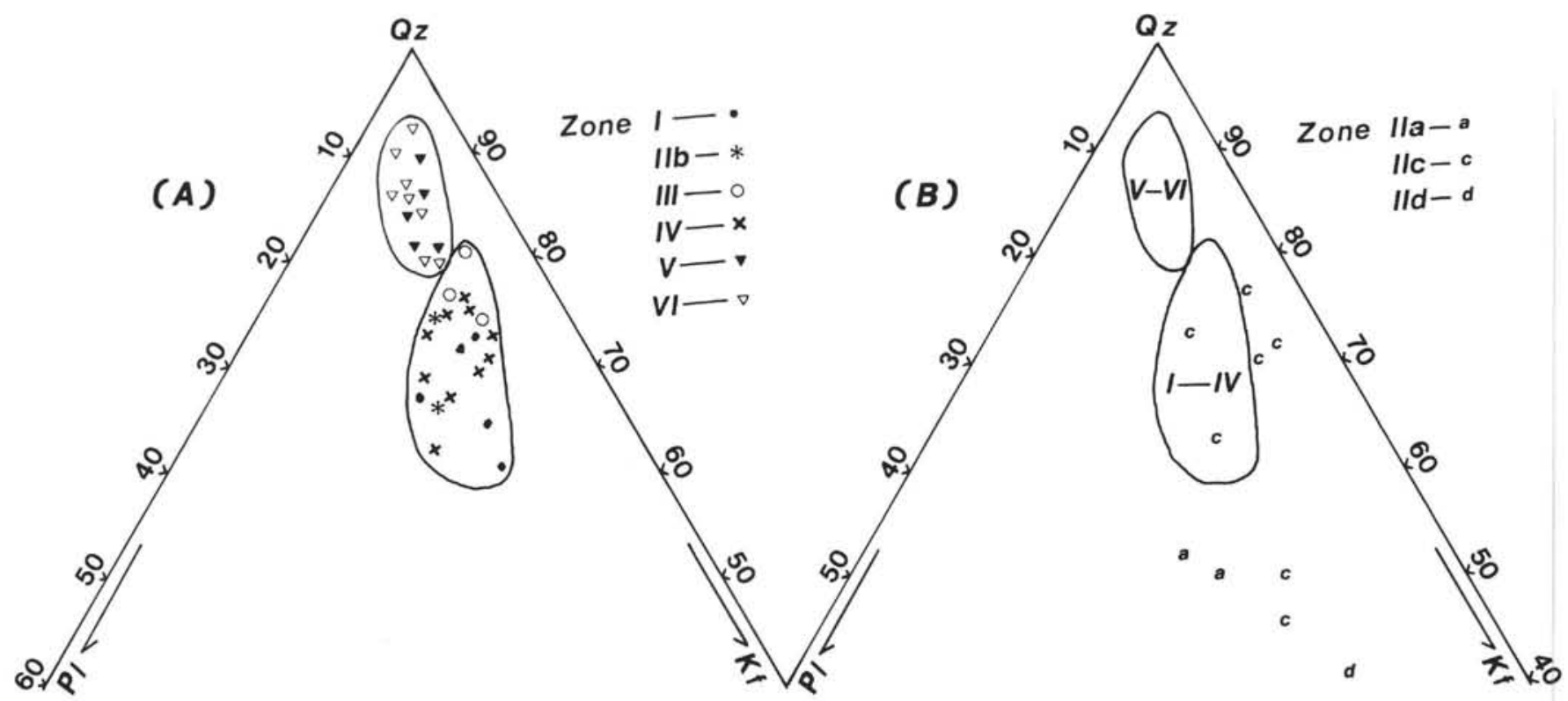

Figure 3. Modal proportions of K-feldspar, albite, and calcic plagioclase $\left(>\mathrm{An}_{10}\right)$. A. Sediments from the Himalayas. B. Sediments from the Indian subcontinent.

\section{MINERAL COMPOSITIONS}

The minerals were analyzed on a Link Systems EDS, using natural and synthetic materials as standards with corrections by the ZAF method (Statham, 1979). Minerals were analyzed from all samples, and the following section summarizes major compositions or compositional ranges in each zone. The chemical compositions of the minerals are compared with those reported from the probable linked drainage basins in the Himalayas, India, and Sri Lanka.

\section{Ilmenite}

Most of the ilmenites in the Bengal Fan are poor in the hematite component and are represented as (Fe, $\mathrm{Mn}$, $\mathrm{Mg}) \mathrm{Ti}_{2} \mathrm{O}_{3}$. MnO and MgO contents are shown in Figure 4. In all the zones except for Zone II, $\mathrm{MnO}$ content ranges from less than $0.5 \mathrm{wt} \%$ to more than $3.0 \mathrm{wt} \%$ and $\mathrm{MgO}$ content is usually less than $0.5 \mathrm{wt} \%$. The ilmenites in the Zone IIc sediments are distinctly different. They are rich in $\mathrm{MgO}$ and have limited variation in $\mathrm{MnO}$ content, similar to those from the Deccan Trap basalts (Fig. 4). Ilmenites in Zone IIb are similar to those from other zones, whereas Zones IIa and IId are commonly $\mathrm{Mg}$-rich with variable $\mathrm{MnO}$.

\section{Plagioclase}

Plagioclase consists of albite to andesine in most zones (Fig. 5), except Zones IIc and IIa. Plagioclase in Zone IIc ranges from albite to labradorite with a bimodal pattern, oligoclase and labradorite being most frequent. Deccan Trap basalts have plagioclases with anorthite content between 50 and 70 (Sen, 1986), indicating that the An-rich plagioclases in Zone IIc may have been derived from the basalts. In contrast, Zone IIa plagioclase has a restricted range in anorthite content with oligoclase predominant. Albite and andesine are rare, suggesting the absence of low-grade metamorphic rocks in the drainage basin.

\section{Garnet}

Variations in pyrope and grossular in garnets from Bengal Fan sediments are shown in Figure 6 and compared with new data on Tethys sediments. These include Permian to Triassic calcareous sandstones from the Salt Range (Pakistan) consanguineous with the Tethys sediments in the Himalayas. Garnets in metamorphic rocks from the Nepal Himalayas and Sri Lanka are also shown in Figure 6. Mn-rich garnets and grossular-andradite series garnets, not uncommon in many zones, are excluded from the diagram. Only magnesium-poor garnets are plotted.

Garnets from Zones IIa and IId sediments have high pyrope contents, clearly different from the others (Fig. 6). The Zone IIa garnets are similar to $\mathrm{Mg}$-rich ones in gneiss from Sri Lanka although the data are limited (Hapuarachchi, 1975). In Zones VI and V, garnets are commonly grossular-rich with a restricted range of pyrope content, whereas in Zones IV to I they have a wider range of pyrope content. Zones IV, IIb, and I have similar ranges of pyrope content and frequency of grossular-rich garnets. Furthermore, they bear some similarity with garnets from the Nepal Himalayas. Zone III sediments contain more grossular-rich garnets than the sediments in Zones I, IV, and the Nepal Himalayas. Garnets in the Tethys sediments are mostly more pyrope-rich than those in the Bengal Fan sediments except for Zones IIa and IId, and are also different from those in Sri Lanka.

\section{Epidote-group Minerals}

Epidote-group minerals have a wide compositional variation (Fig. 7). Epidotes in Zones VIa and IId differ from the others. Zone VI is divided into two subzones by the frequency of zoisite in the epidote-group minerals, even though there is no clear difference in modal proportions and chemical compositions of the other minerals within the zone. The upper subzone (VIa) is rich in zoisite, whereas the lower zone (VIb) is similar to the other zones (Fig. 1 and 7). A clay bands, $10 \mathrm{~m}$ thick, is present between the subzones. In Zone IId, the epidote-group minerals have a more restricted compositional range than in other zones.

\section{Calcic Amphiboles}

Calcic amphiboles are mostly bluish to brownish green hornblendes. However, brown hornblende is predominant in 


\section{ilmenite}
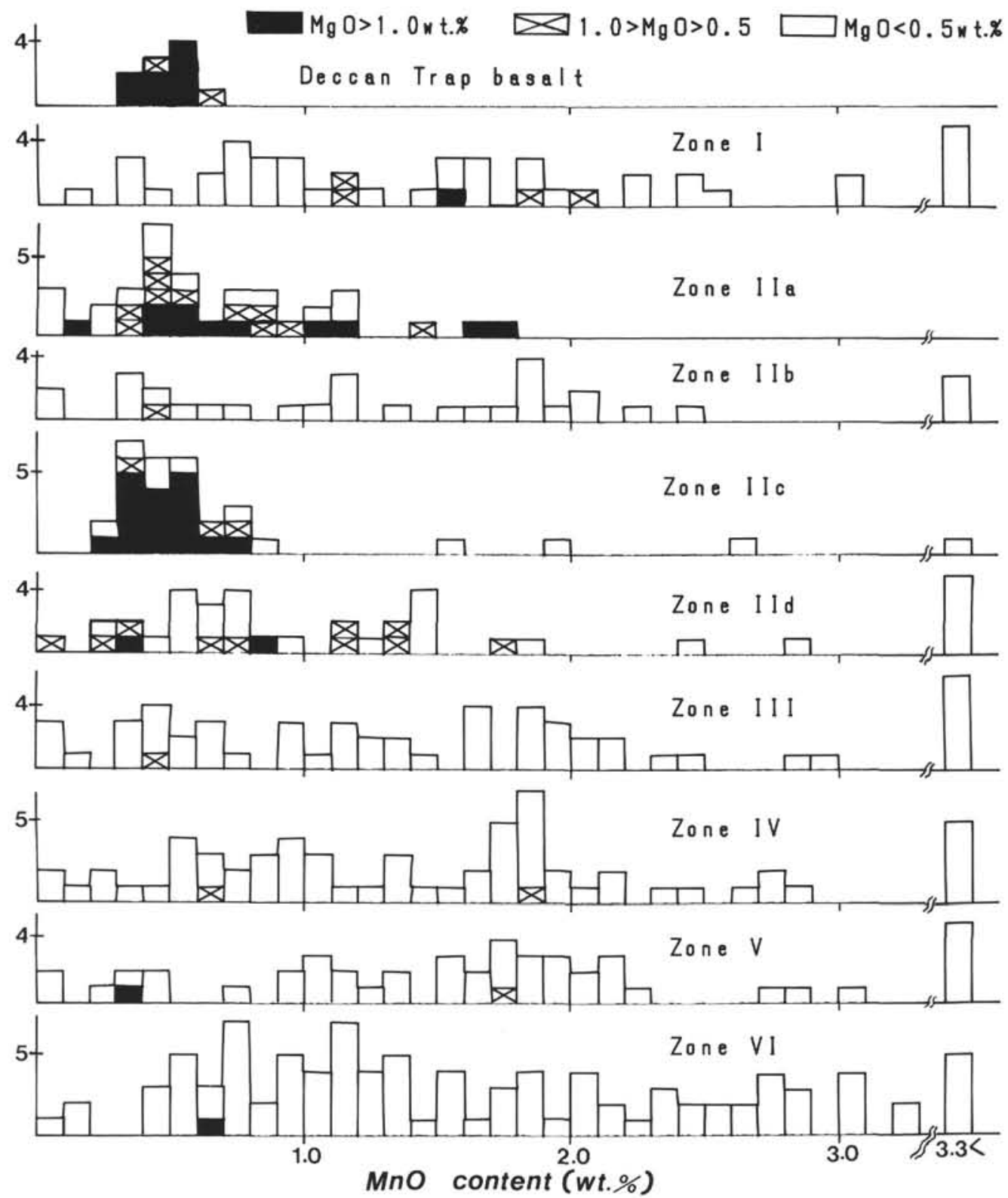

Figure 4. Variation of $\mathrm{MnO}$ content in ilmenite (three ranges). Vertical axes show the number of analyses. Data from the Deccan Trap basalts are from Sen (1986).

Zone IIa and is common in Zones IIc and IId. This difference is also shown by their $\mathrm{Al}_{2} \mathrm{O}_{3}$ and $\mathrm{TiO}_{2}$ contents (Fig. 8). Hornblende in $\mathrm{Zone} \mathrm{IIa}$ has a restricted $\mathrm{Al}_{2} \mathrm{O}_{3}$ range and is rich in $\mathrm{TiO}_{2}$.

\section{Olivine}

Olivine is present only in Zone I sediments that were derived from a drainage system similar to that of the present day. All the olivine grains observed are rich in forsterite $(>$ Fo $=88)$ with a possibly bimodal chemical distribution (Fig. 9). Compositional ranges of olivine in many rock types have been well studied (e.g., Deer et al., 1982). The forsterite-poor olivines were probably derived from ultramafic rocks such as lherzolite and harzburgite, and the Fo-rich ones were from carbonate rocks metamorphosed at high temperature.

\section{Pyroxenes and Calcium-poor Amphibole}

Pyroxenes and calcium-poor amphiboles are plotted in Figure 10. The orthopyroxene from Zones V, IV, and III to IIb is enstatite; hypersthene occurs in Zones IIa and I. Pyroxenes from the Bengal Fan rarely plot in the range as those in the Deccan Trap basalts (Fig. 10), even in Zone IIc where plagioclase and ilmenite have strong affinities with those of the Deccan basalts. This discrepancy may be explained as either pyroxenes being far less abundant than plagioclase and ilmenite in the Deccan Trap basalts, or as pyroxenes undergoing selective breakdown during transportation.

\section{DISCUSSION}

As the main deep-sea channels in the Bengal Fan are clearly connected with the Ganges-Brahmaputra river system 


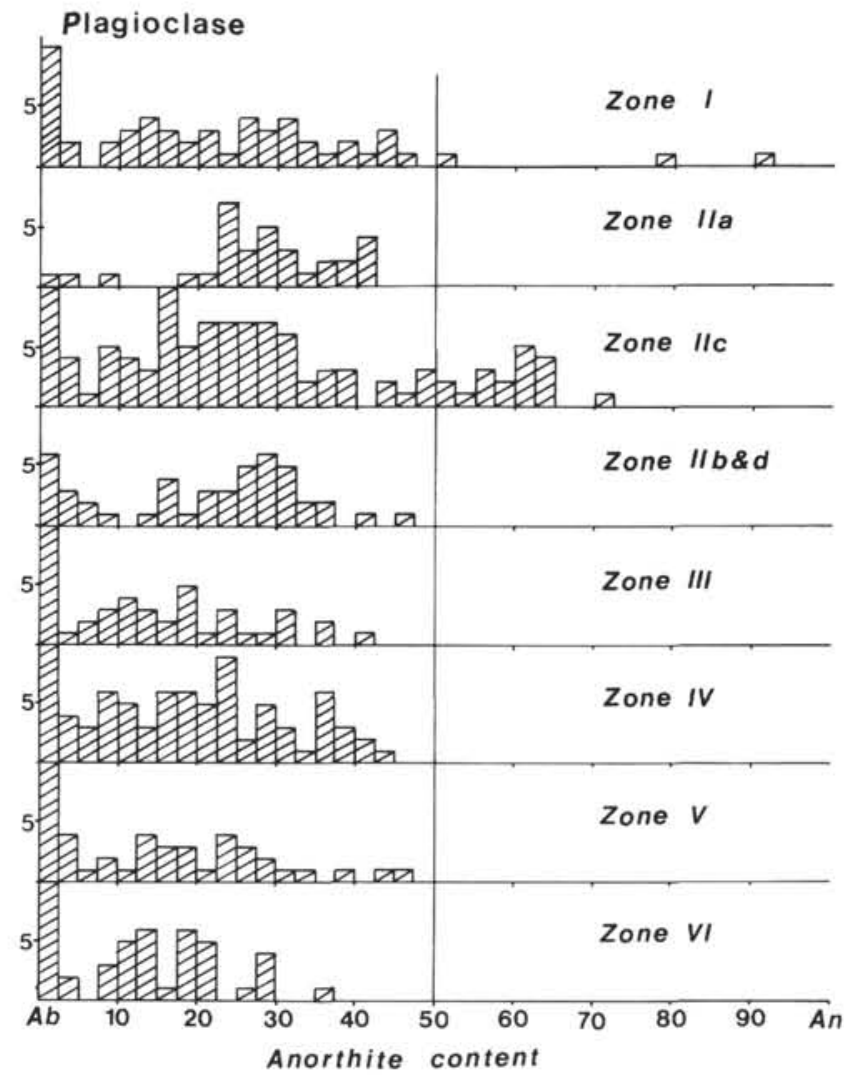

Figure 5. Variation of anorthite content in plagioclase. Vertical axes show the number of analyses. Ab is albite.

(Curray and Moore, 1974), and the deposition of such an enormous amount of fan sediments can only be explained by uplift and succeeding erosion of a large hinterland, it is clear that the main source area for the Bengal Fan sediments lies in the Himalayas (e.g., Curray and Moore, 1974; Emmel and Curray, 1984). This suggestion is supported by the present study, but there appear to be some sediments with a different source. These are Zones IIa, IIc, and IId sediments, which have mineral compositions comparable to some volcanic and metamorphic rocks in the Indian subcontinent (Figs. 4, 5 and $6)$.

\section{Sediments from the Indian Subcontinent}

Zone IIc sediments are characterized by abundant Mg-rich ilmenite and An-rich plagioclase. Their compositions are comparable with those of the Deccan Trap basalts, suggesting that the rivers supplying the sediments ran through the Deccan Trap. Using the present river system as an analog, there are three possible candidates for the Zone IIc sediments (Fig. 11). They run mainly through the Precambrian-Paleozoic terrain with sedimentary and metamorphic rocks, in addition to the Deccan Trap (Crawford, 1974). Although we could not match the details of the metamorphic rocks in the Indian subcontinent, garnet and calcic amphiboles in Zone IIc are different from those derived from the Himalayas (Figs. 6 and 8 ) in that pyrope-rich garnet commonly occurs in conjunction with brown hornblende, suggesting the widespread presence of high-grade rocks in the drainage basin.

Zone IIa sediments are characterized by an abundance of sillimanite and scarcity of epidote and albite. Compositions of garnets are similar to those in the gneiss from Sri Lanka. Sri Lanka and the southern part of India consist mostly of granulite facies rocks such as garnet-biotite gneiss, sillimanite gneiss, and basic granulite (Hapuarachchi, 1975; Crawford, 1974). The Zone IIa mineral assemblage and compositions are, therefore, comparable with Sri Lankan and southern Indian rocks. The $\mathrm{Mg}$-rich ilmenite with various $\mathrm{MnO}$ contents and abundant brown hornblende in Zone IIa can also be matched to minerals present in the granulite-facies region.

The Zone IId sediments are characterized by abundant anthophyllite-cummingtonite and the common presence of $\mathrm{Mg}$-rich garnet and ilmenite. Possible candidates for the river that supplied the sediments are shown in Figure 11. The mineral compositions suggest that the river kept away from the Deccan Trap but flowed through the greenschist-to-granulite facies terrains where anthophyllite schists occur (Crawford, 1974; Rao, 1974). Common Mg-rich garnet and ilmenite suggest that the drainage basin of the river included granulite facies rocks, higher grade than those of the sediments of Himalayan origin. Albite, epidote, and calcic amphibole with variable $\mathrm{Al}_{2} \mathrm{O}_{3}$ content are comparable with the amphibolite and greenschist-facies rocks.

The sediments derived from the Indian subcontinent are recognizable only in the clay-rich zone. The deep-sea channels connected with the Ganges-Brahmaputra river system have changed their courses many times and there are many abandoned channels in the Bengal Fan (Curray and Moore, 1974). The present main channel runs close to Sites 717-719. If a channel had run far from the sites, the clay material deposited would have a lesser Himalayan contribution. Even though sediments were supplied steadily from the Indian subcontinent, it would be difficult to find such sediments in the Bengal Fan because of the enormous sediment supply from the Himalayas. Thus, sediments from the Indian subcontinent are recognizable only in a clay-rich sequence, formed during slow sedimentation due to shifting of the main channel far from the sites in question.

\section{Sediments Derived from the Himalayas}

As most of the sediments in the Bengal Fan were derived from the Himalayas, minerals in the sediments were compared with those in the Himalayas and with Tertiary sediments deposited along their southern flank. As Zone I sediments are Quaternary, we first compared the minerals in the sediments with those in the present drainage basin of the Ganges and Brahmaputra rivers.

The Himalayan region is generally divided into four units as shown in Figure 11 (Gansser, 1964): the Tethys Himalayas, Higher Himalayas, Lower Himalayas, and Sub Himalayas. The Tethys Himalayas are composed mainly of sedimentary rocks such as limestone, calcareous sandstone, and dolomite of Permo-Triassic age, although some parts of this domain were strongly metamorphosed during the Tertiary. The Higher Himalayas are composed of various metamorphic and granitic rocks. The Lower Himalayas are composed mostly of non- or weakly metamorphosed sedimentary rocks of the Precambrian and Paleozoic and have been partially overridden by the metamorphic nappes sheets of the Higher Himalayas. The Sub Himalayas are composed of Tertiary to early Pleistocene sediments. These domains are separated by tectonic boundaries, some of which are still active today (Morgan and McIntire, 1959; Baker et al., 1988).

\section{Zone I}

According to petrological studies of the metamorphic and granitic rocks from the Higher Himalayas (e.g., Gansser, 1964; Ishida and Ohta, 1973), plagioclase is mostly albite to andesine. Calcic amphibole in the Higher Himalayas is mostly bluish-green hornblende. Garnet is a common mineral in both 


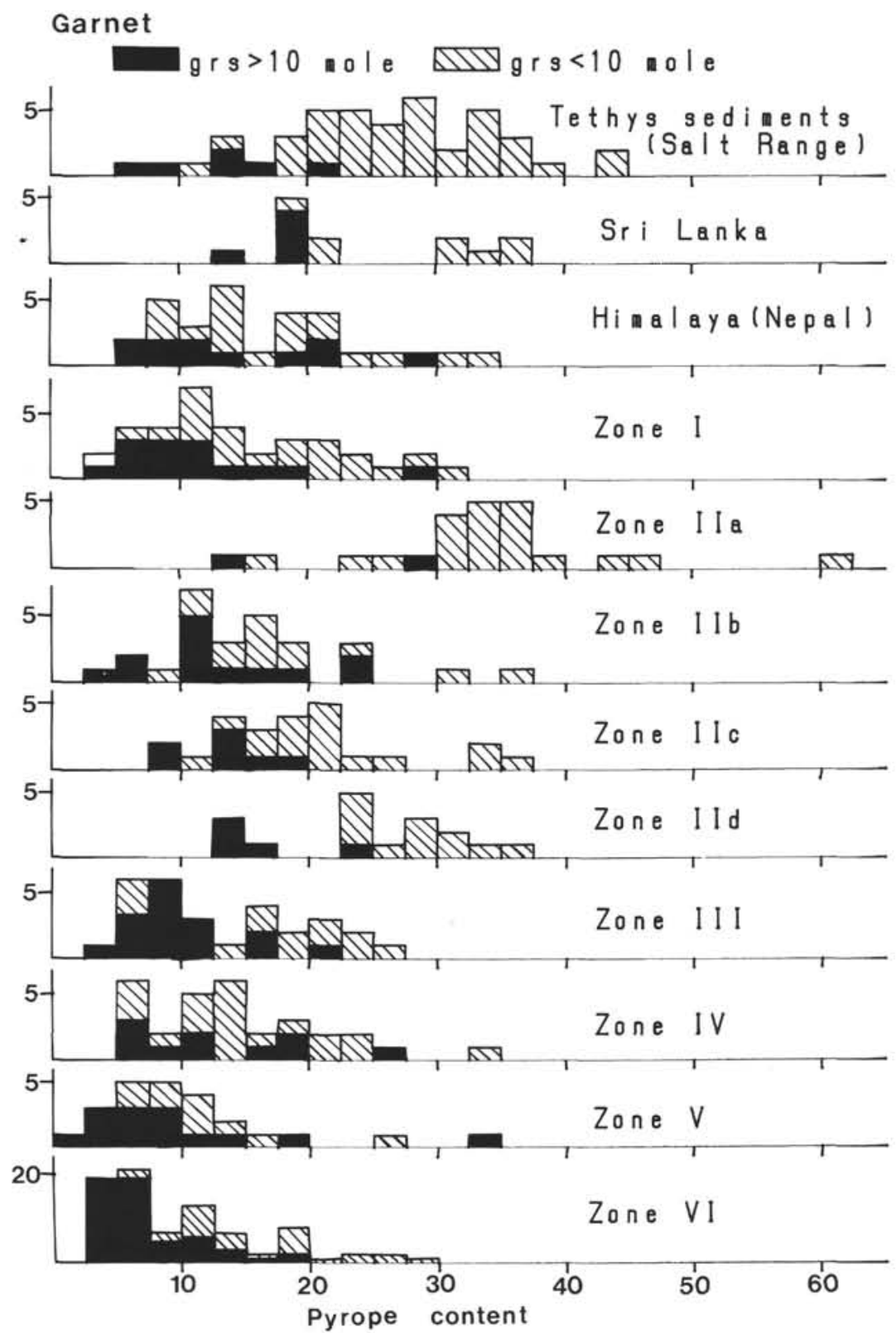

Figure 6. Pyrope content in garnet. Mn-rich garnet (spessartine content $>5 \%$ ), grossular, and andradite are excluded from this diagram. Data: Tethys sediments (this study), Sri Lanka (Hapuarachchi, 1975; Hiroi, unpubl. data), Nepal Himalayas (Lal and Ackermand, 1981; Maruo and Kizaki, 1983; Yonekura, unpubl. data). Vertical axes show the number of analyses.

the biotite schist and gneiss, and its compositional range is quite similar to that of the Zone I (Fig. 6). A large peridotite body occurs in the Central Himalayas as a thrust sheet overlying the Tethys Himalayas (Fig. 11), which supplies olivine with Fo values around 90 to the Ganges and Indus rivers (Gansser, 1964). Olivines with Fo of 88-92 in Zone I sediments may be related to the unroofing of this peridotite, although occurrences of enstatite, chromian spinel, and serpentine in the underlying zone show the erosion of serpentinized peridotite before the Zone I stage. The calcium-poor hypersthene in Zone I may have been derived from the granulite in the Higher Himalayas (Sinha Roy, 1977).

Characteristics of plagioclase, garnet, amphibole, and epidote in Zone I are explained by the major constituents in the Higher Himalayas, and by marker minerals such as olivine and hypersthene that can also be related to specific source regions in the Himalayas. The present drainage basins of the Ganges and Brahmaputra rivers cover a wide area including the Deccan Trap and Tibetan Plateau. As higher regions undergo the most rapid erosion, it is not surprising that the Higher and Tethys Himalayas are the dominant source region for the major and marker minerals in Zone I. Of these main source areas, a relatively small contribution from the Tethys Himalayas can be expected, because for much of its course the Brahmaputra River is too flat-lying on the Tibetan side to transport much clastic material.

\section{Zone VI-II}

During Zone VI (about 17-15 Ma in Fig 1), the Himalayas were already high enough to supply enormous quantities of 


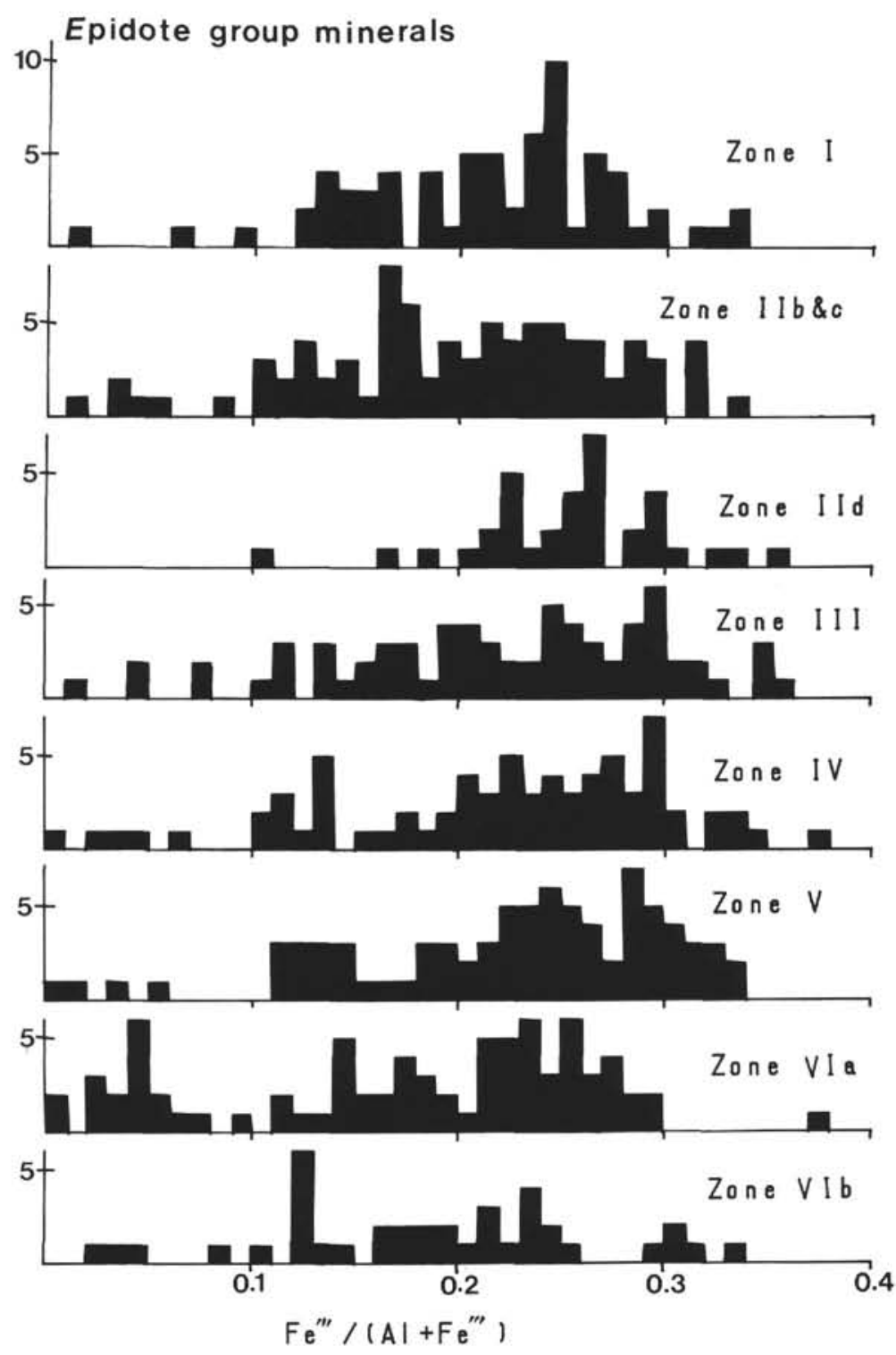

Figure 7. $\mathrm{Fe} /(\mathrm{Al}+\mathrm{Fe})$ ratios in epidote-group minerals. Vertical axes show the number of analyses.

sediment to the Fan. Zone VI sediments are characterized by abundant quartz and relatively scarce calcic plagioclase in the light fraction, and by abundant dolomite and scarce hornblende in the heavy fraction. Hence, it is most probable that these sediments were derived mainly from non- to weakly metamorphosed sedimentary rocks such as quartzite, carbonate rock, and sandstone. Metamorphic rocks were apparently rare at this time, supported by the $\mathrm{K}-\mathrm{Ar}$ isotope ages of metamorphic rocks in the Himalayas, which are mostly less than 17 Ma (Gansser, 1964). Unroofing of metamorphic rocks therefore took place after $17 \mathrm{Ma}$. The chemical compositions of garnets, rich in grossular and poor in pyrope, suggest that they were derived neither from the Tethys sediments nor from the Indian subcontinent (Fig. 6). The Precambrian and Paleozoic sediments in the Lower Himalayas are the most likely source of these garnets.

Zone VI is subdivided into $\mathrm{a}$ and $\mathrm{b}$ based on the frequency of zoisite in the epidote-group minerals, but we could not identify the original source material for the zoisite in the
Himalayas. This material might have been subsequently eroded away or might still be locally present in the Lower Himalayas.

Zone V is transitional between Zones VI and IV. Amphiboles with variable $\mathrm{Al}_{2} \mathrm{O}_{3}$ content and pumpellyite occur persistently throughout this and younger zones although the major heavy minerals, except epidote, are less abundant here. These characteristics suggest that metamorphic rocks were undergoing active erosion at this time and that the higher part of the drainage basin was composed mainly of metamorphic rocks and pre-Mesozoic sediments.

The modal proportion of calcic amphibole changes abruptly from Zone VI to V and from Zone V to IV. Either the major constituents in the drainage basin or the basin itself changed abruptly, or there was a long period of slow sedimentation while the channel shifted away from the drill sites. Although the latter is supported by the presence of clay layers between the zones, we suggest that the former is more probable because thrusting and uplift were active in the Himalayas after the early Miocene (e.g., Zeitler et al., 1982). 


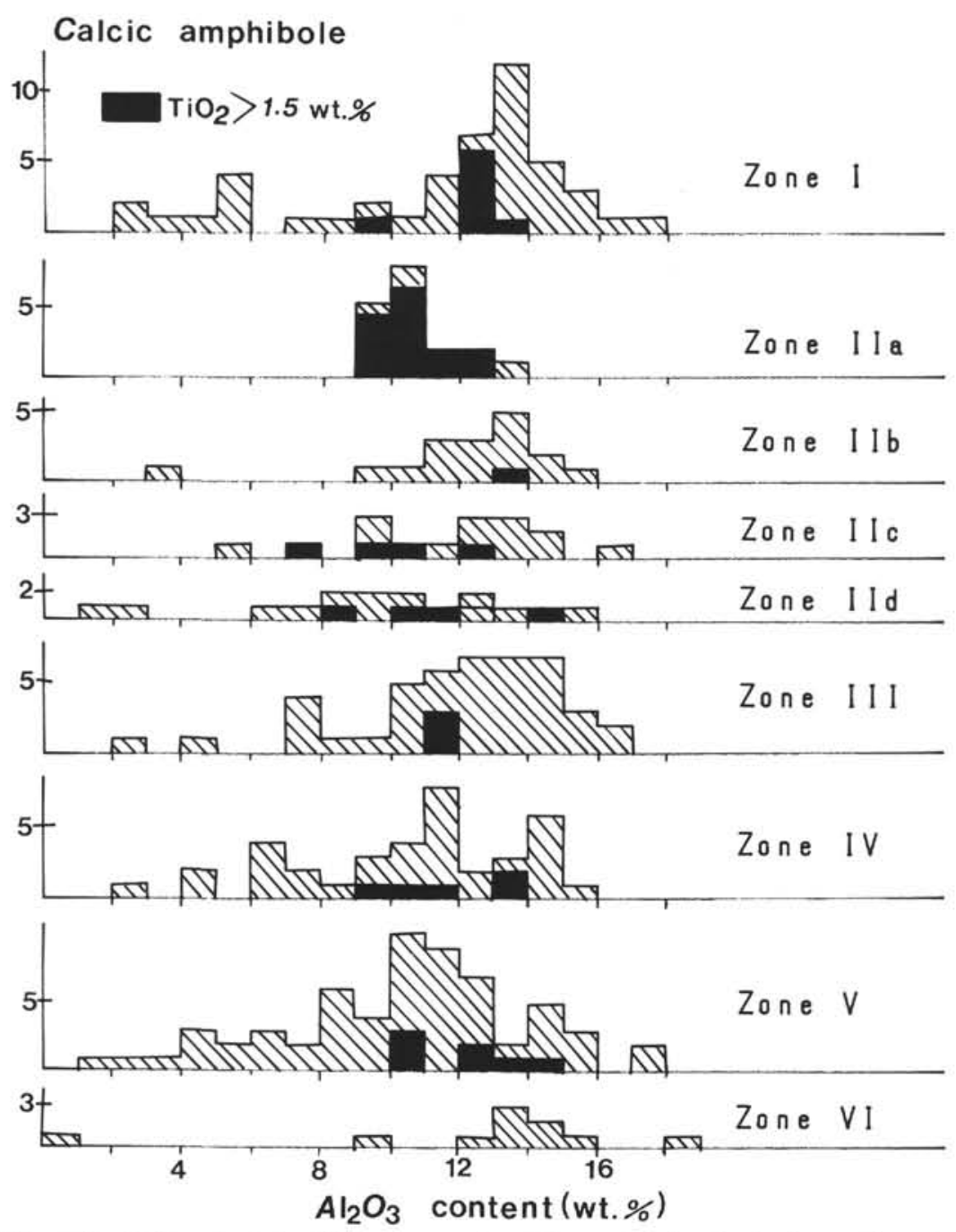

Figure $8 . \mathrm{Al}_{2} \mathrm{O}_{3}$ and relative $\mathrm{TiO}_{2}$ contents in calcic amphibole. Vertical axes show the number of analyses.

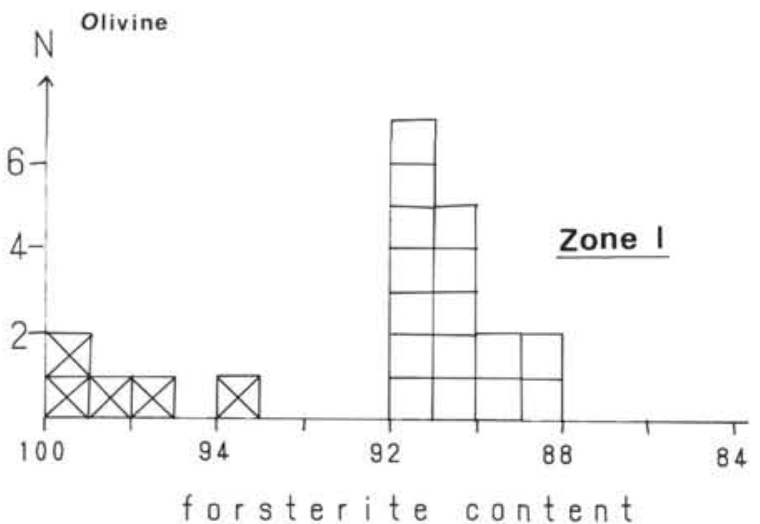

Figure 9. Forsterite contents in olivines from Zone I sediments. Olivines around $\mathrm{Fo}_{90}$ were derived from peridotite, whereas almost pure forsterites were derived from metamorphosed carbonate rocks (details in text). Vertical axes show the number of analyses.
As mentioned before, mineral proportions and compositions of Zone IV sediments are similar to those of Zone I sediments. The major minerals suggest that the metamorphic rocks of the source region were widely exposed at the time of Zone IV (about 10-15 Ma) and the Himalayas of that time had major constituents similar to the present Himalayas of the Ganges-Brahmaputra drainage basin. The only significant difference is the lack of evidence for erosion of peridotite and granulite during Zone IV.

The modal proportion of calcic amphibole decreases abruptly from Zone IV to Zone III. The mineral assemblages and relative modal abundances in Zone III are more like those in Zone V than to those in Zone IV. As Zone III is relatively rich in quartz, it is probable that metamorphic rocks were less abundant in the Zone III drainage basin than in the Zone IV, and the present Ganges-Brahmaputra basins, and that the Zone III minerals were derived from metamorphic rocks with a subordinate contribution from the Precambrian and Paleozoic sediments. The latter interpretation is supported by the similarity of garnet compositions in Zones III and V (Fig. 6).

Pumpellyite disappears within Zone III. It occurs rarely in the Lower Himalayas in the drainage basin of the GangesBrahmaputra rivers (Sinha Roy, 1977), but is common in the Indus river basin (Honegger et al., 1982). The disappearance 

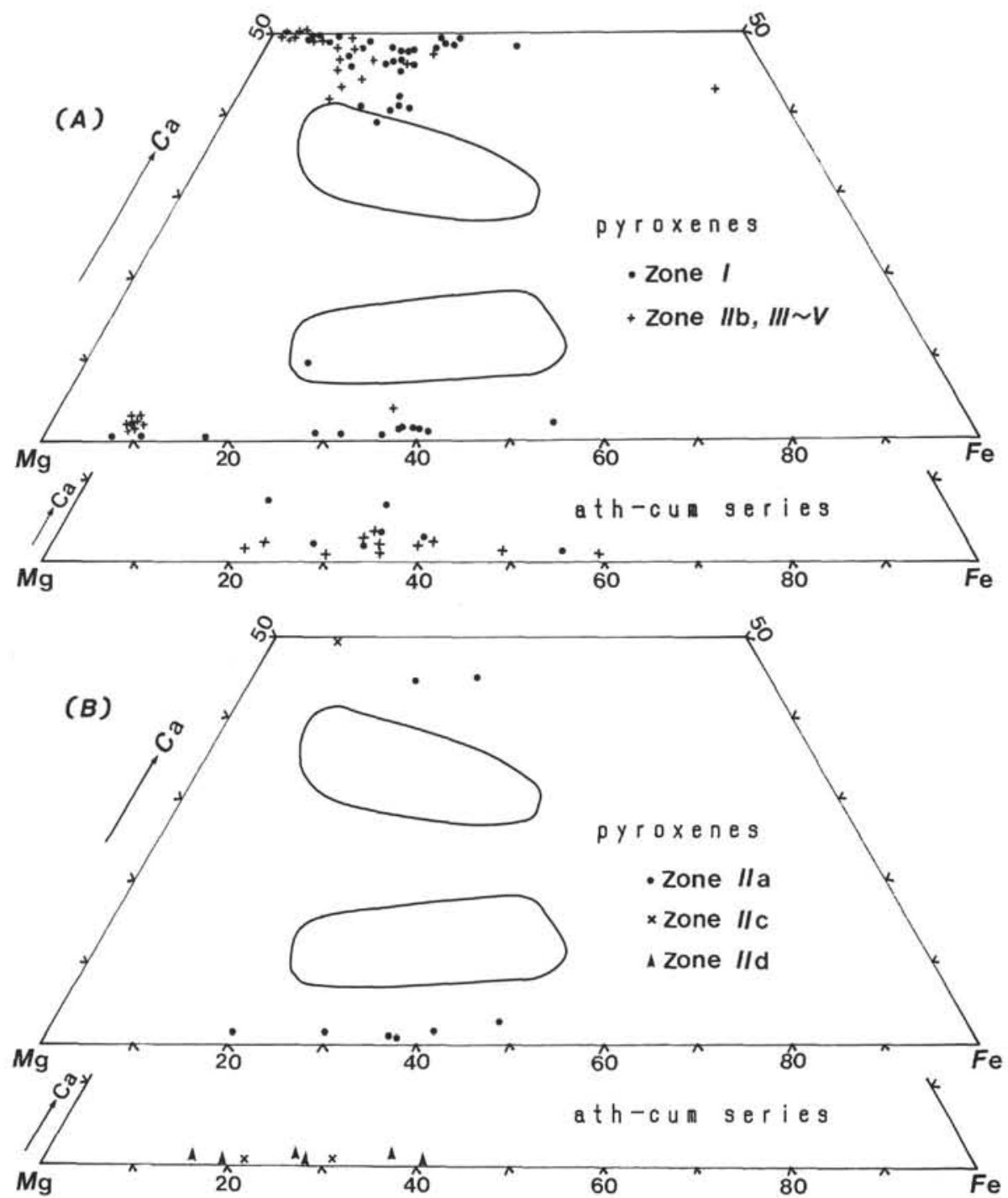

Figure 10. Pyroxene and calcium-poor amphibole compositions from A. The Himalayas, B. The Indian subcontinent. Compositional ranges of the pyroxenes from the Deccan Trap basalts (Sen, 1986) are enclosed by solid lines.

of pumpellyite may, therefore, be explained by almost complete erosion of pumpellyite-bearing rocks, or by a change of drainage pattern. Further speculation on the causes of the disappearance of the pumpellyite and substantial decrease of amphibole are not warranted at present.

From Zone III to the middle of Zone II (IIb) there is a gradual decrease in the relative abundance of calcic amphibole, followed by an increase toward Zone I (Fig. 1). There is no clear difference in the chemical compositions of major minerals between Zones II and I. Changes in modal proportions relate to changes in the ratio of the main constituents in the drainage basin, returning to the same configuration in Zone IV.

\section{Comparisons with Tertiary Sediments in the Sub-Himalayas}

The Siwalik Group, located more than $3000 \mathrm{~km}$ from the drilled sites, is similar in age to the sediments from the Bengal Fan. Many workers have studied heavy minerals in the Siwalik Group (Gill, 1951; Sinha, 1970; Chaudhri, 1972) and its equivalents in Assam (Sinha and Sastri, 1973). These workers identified a number of marker minerals for their subgroups: staurolite, kyanite, sillimanite, and andalusite. These minerals are not found in large quantities in the Bengal Fan sediments derived from the Himalayas. The heavy minerals from the Siwalik sediments differ from those in the Bengal Fan in that they are highly weathered near the earth's surface (Wadia, 1961) and have suffered selective alteration of minerals (Sinha, 1970). The lack of olivine in the Siwalik Group may be due to such weathering. It is difficult to compare the modal proportions of minerals in the Siwalik Group and Bengal Fan sediments because of selective sorting according to density and size in addition to the weathering. Consequently, only appearances of the more resistant minerals can be compared (Fig. 12).

Garnet, tourmaline, zircon, and opaque minerals are persistent in all samples from the Sub Himalayas and Bengal Fan. In Punjab, zoisite appears after epidote, followed by bluish green hornblende. In Assam, hornblende appears after epidote and zoisite, followed by enstatite. Based on the abrupt increase of bluish green hornblende in sediments at Potwar, Pakistan, Johnson et al. (1985) concluded that the metamor- 


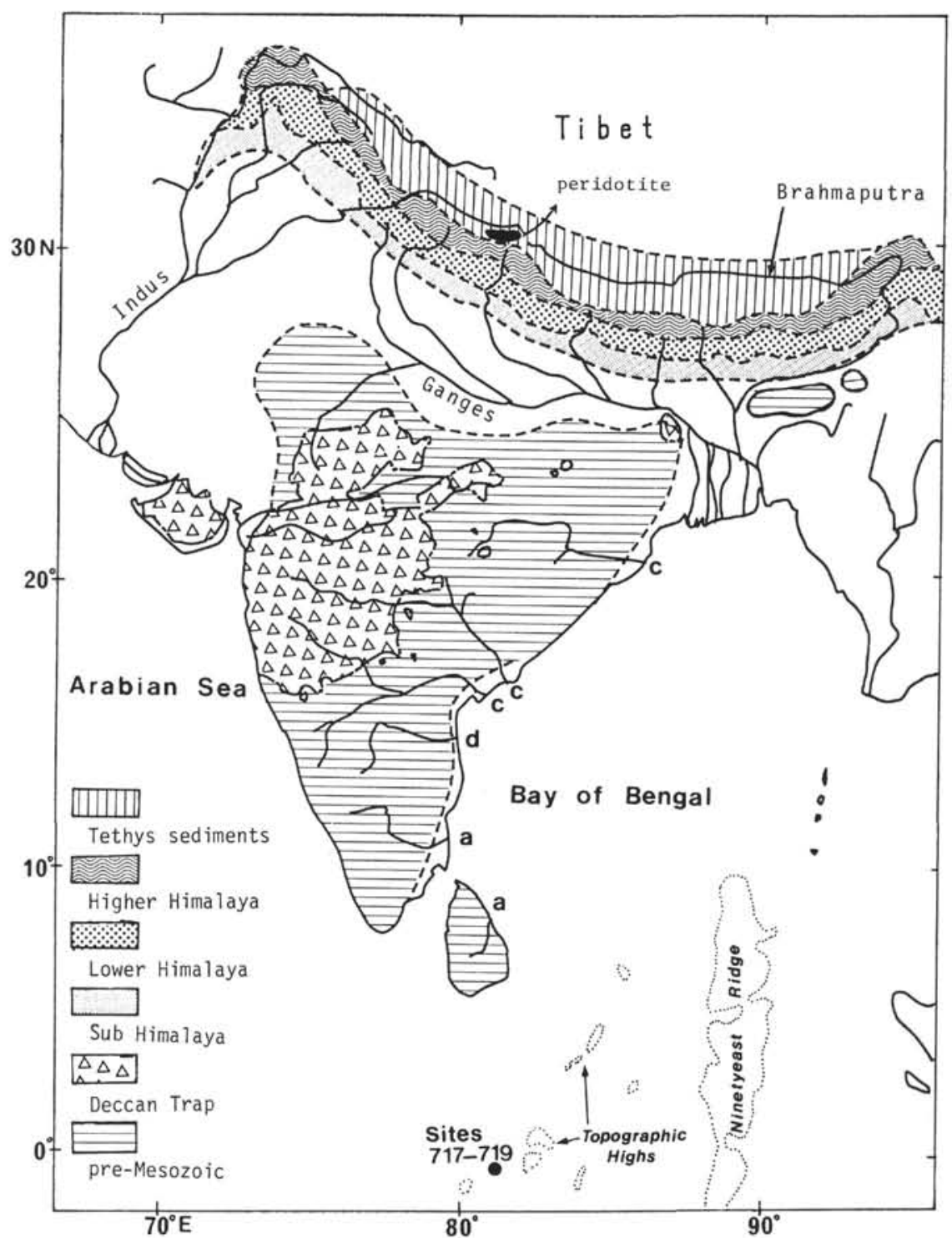

Figure 11. The general subdivisions in the Himalayas and the Indian subcontinent. The rivers that supply sediments similar to those of Zones IIa, IIc, and IId, are shown as a, c, and $\mathrm{d}$ at the western coast of the Bay of Bengal.

phic terrain was unroofed over a wide front after $11 \mathrm{Ma}$. Although our interpretation from the Bengal Fan sediments is that the first unroofing was at about $15 \mathrm{Ma}$ (Zone V), their 11-Ma event is consistent with a subsequent wide unroofing of the metamorphic terrain at about $11 \mathrm{Ma}$ (Zone IV). Even though comparisons are rough and the stratigraphic position of mineral appearances varies at different localities within the Siwalik Group (Chaudhri, 1972), it appears that the Miocene sediments from the Sub Himalayas and Bengal Fan record similar tectonic events within the Himalayan source area.

Pilgrim (1913) first proposed a "Siwalik River" running from east to west along the southern front of the Himalayas. Johnson et al. (1985) concluded, on the basis of cross-bedding studies in the West Himalayas, that for some $16 \mathrm{~m} . \mathrm{y}$. the Siwalik River ran from west to east. The similarity of the Tertiary sediments along the Himalayas and from the Bengal Fan also suggests that a large river had once run from west to east and supplied consanguineous sediments to both regions. The Siwalik River later separated into the Indus and Ganges-
Brahmaputra rivers, which should have caused a change of modal proportions in the Bengal Fan sediments. There are four major changes in the Bengal Fan sedimentary sequence (substantial decrease of amphibole from the Zones IV to III, disappearance of pumpellyite, increase of amphibole in Zone II, and appearance of olivine), and one of these must correlate with the separation of the Siwalik River. By reference to the Johnson et al. (1985) interpretation of the duration of the flow direction, it is probable that the Siwalik River divided around the time of unroofing of the Jungbwa peridotite body in the Central Himalayas, which borders the Indus and Ganges drainage basins, between 3.5 and $0.5 \mathrm{Ma}$ (see Fig. 1).

Based on the flow directions of tributaries of the Brahmaputra River in Tibet, Burrard and Hayden (1934) concluded that the Brahmaputra River had once run from east to west along the northern front of the Himalayas and that the river probably flowed through the Central Himalayas to join with the Ganges. The change of flow direction of the Brahmaputra River may be explained by the uplift of the Central Himalayas 

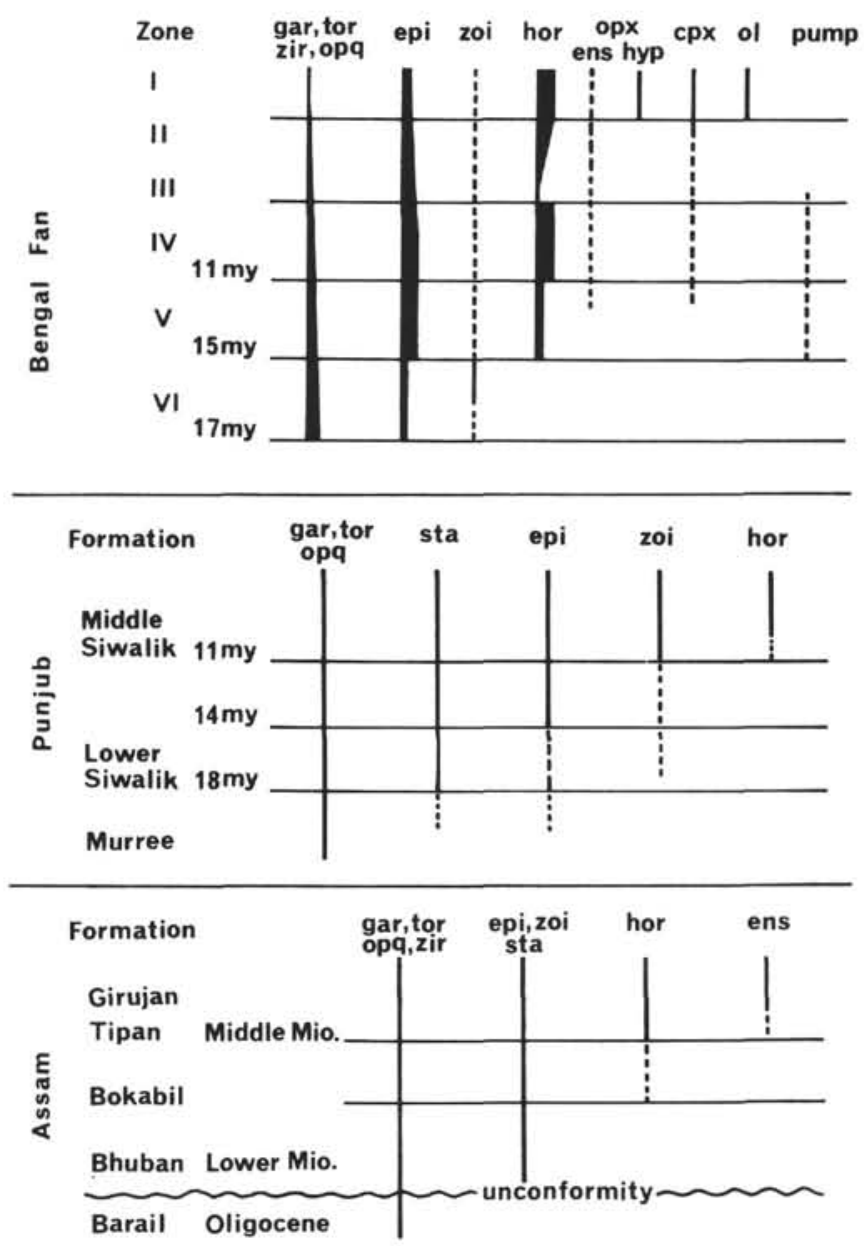

Figure 12. Comparison of mineral appearances in the sediments from the Bengal Fan with those of Punjab (Sinha, 1970) and Assam (Sinha and Sastri, 1973). The ages in Punjab are from Johnson et al. (1985).

around the same time that the Siwalik River separated, because the peridotite body occurs almost at a triple junction of the drainage basins of the three rivers (Fig. 11).

\section{CONCLUSIONS}

1. The sediments in the Bengal Fan were mostly derived from the Himalayas, with a lesser contribution from the Indian subcontinent. The latter are recognizable only in a clay-rich zone deposited when the main deep-sea channel is far from the drilled sites.

2. The Bengal Fan sediments derived from the Himalayas are essentially similar to the Siwalik Group and its equivalents at the southern flank of the Himalayas.

3. The Zone VI sediments (17-15 Ma), the oldest recovered from the Bengal Fan, were derived mostly from the Precambrian and Paleozoic sedimentary rocks such as quartzite, carbonate rock, and sandstone occurring in the Lower Himalayas. Tethys sediments made only a very small contribution to Zone VI.

4. In the Himalayas, the main metamorphic terrain was first unroofed at $15 \mathrm{Ma}$, with wide unroofing at around $11 \mathrm{Ma}$. After $10 \mathrm{Ma}$ there were few drastic changes in sediment mineralogy, implying stability in the drainage pattern. A large peridotite body in the Central Himalayas was unroofed between 3.5 and $0.5 \mathrm{Ma}$.
5. The present Ganges and Brahmaputra rivers supplied the Zone I sediments ( $<1 \mathrm{Ma})$, whereas older sediments from Zones VI to II were brought by the Siwalik River, which flowed west to east along the southern front of the Himalayas. The Siwalik River was separated into the Indus and Ganges rivers due to the uplift of the Central Himalayas around the time of the unroofing of the peridotite body.

\section{ACKNOWLEDGMENTS}

We are very grateful to $\mathrm{S}$. Wallis for his critical reading of this manuscript and M. Shigeoka for her help in modal and chemical analyses and heavy mineral separations throughout this study. We also thank Y. Hiroi, Y. Maruo, and T. Yonekura for enabling us to use their unpublished data.

\section{REFERENCES}

Baker, D. M., Lillie, R. J., Yeats, R. S., Johnson, G. D., Yousuf, M., and Zamin, A.S.H., 1988. Development of the Himalayan frontal thrust zone: Salt Range, Pakistan. Geology, 16:3-7.

Burrard, S. G., and Hayden, H. H., 1934. A Sketch of Geography and Geology of the Himalayan Mountain and Tibet: Calcutta (Govt. of India Press).

Chaudhri, R. S., 1972. Heavy minerals from the Siwalik formations of the Northwestern Himalayas. Sediment. Geol., 8:77-82.

Crawford, A. R., 1974. Indo-Antarctica, Gondwanaland, and the distortion of a granulite belt. Tectonophysics, 22:141-157.

Curray, J. R., and Moore, D. G., 1974. Sedimentary and tectonic processes in the Bengal Deep-sea Fan and geosyncline. In Burk, C. A., and Drake, C. L. (Eds.), Continental Margins: New York (Springer-Verlag), 617-627.

Deer, W. A., Howie, R. A., and Zussman, J., 1982. Rock-forming Minerals-Orthosilicates: London and New York (Longman Group Ltd.).

Emmel, F. J., and Curray, J. R., 1984. Bengal Fan, Indian Ocean. In Bouma, A. H., Normark, W. P., and Barnes, N. E. (Eds.), Submarine Fans and Related Systems: New York (Springer Verlag), 248-275.

Gansser, A., 1964. Geology of the Himalayas: London (John Wiley and Sons Ltd.).

Gill, W. D., 1951. The stratigraphy of the Siwalik Series in the northern Potwar, Punjab, Pakistan. Geol. Soc. London Quat. J., 107:375-394.

Hapuarachchi, D.J.A., 1975. The granulite facies in Sri Lanka. Geol. Surv. Sri Lanka, Prof. Paper, 4:1-29.

Honegger, K., Dietrich, V., Frank, W., Gansser, A., Thoni, Trommsdorff, V., 1982. Magmatism and metamorphism in the Ladakh Himalayas (the Indus-Tsangpo suture zone). Earth Planet. Sci. Lett., 60:253-292.

Ishida, T., and Ohta, Y., 1973. Ramechhap-Okhaldhunga region. In Hashimoto, S. (Superviser), Geology of the Nepal Himalayas: Sapporo, Japan (Himalayan Commitee of Hokkaido Univ.), 35 67.

Johnson, N. M., Stix, J., Tauxe, L., Cerveny, P. F. and Tahirkheli, R.A.K., 1985. Paleomagnetic chronology, fluvial processes, and tectonic implications of the Siwalik deposits near Chinji village, Pakistan. J. Geol., 93:27-40.

Lal, R. K., and Ackermand, D. A., 1981. Deformation and Barrovian metamorphism at Takdah, Darjeeling (Eastern Himalaya). In Saklani, P. S., (Ed.), Metamorphic Tectonites of the Himalaya: Lahore (Inst. of Geology, Punjab Univ.), 231-278.

Maruo, Y., and Kizaki, K., 1983. Thermal structure in the nappes of the eastern Nepal Himalayas. In Shams, F. A. (Ed.). Granites of Himalayas, Karakorum \& Hindukush: Lahore (Inst. of Geology, Punjab Univ.), 271-286.

Morgan, J. P., and McIntire, W. G., 1959. Quaternary geology of the Bengal Basin, East Pakistan and India. Bull. Geol. Soc. Am., 70:319-342.

Pilgrim, G. E., 1913. The correlation of the Siwaliks with the mammal horizons of Europe. Rec. Geol. Surv. India, 43:264-325.

Rao, T. R., 1974. A bedded deposit of anthophyllite schist in the Precambrian belt of Nellore, South India. Geol. Mag., 111:221228. 
Sen, G., 1986. Mineralogy and petrogenesis of the Deccan Trap lava flows around Mahabaleshwar, India. J. Petrol., 27:627-663.

Sinha, R. N., 1970. Heavy mineral investigations in the Siwaliks of Mohand, District Saharanpur, Uttar Pradesh, India. J. Geol. Soc. India, 11:163-177.

Sinha, R. N. and Sastri, V. V., 1973. Correlation of the Tertiary geosynclinal sediments of the Surma Valley, Assam, and Tripura State (India). Sediment. Geol., 10:107-134.

Sinha Roy, S., 1977. Metamorphism and tectonics of the Himalayas, as illustrated in the eastern Himalayas. Geotectonics, 11:120124.

Statham, P. J., 1979. A ZAF procedure for microprobe analysis based on measurement of peak-to-background ratios. In Newburry, D. E., (Ed.) Microbeam analysis: San Francisco (San Francisco Press), 247-253.

Thompson, R. W., 1974. Mineralogy of sands from the Bengal and Nicobar Fans, Sites 218 and 211, eastern Indian Ocean. In von der
Borch, C. C., Sclater, J. G., et al. (Eds.), Init. Repts. DSDP, 22: Washington (U.S. Govt. Printing Office), 711-713.

von der Borch, C. C., and Trueman, N. A., 1974. Dolomitic basal sediments from northern end of Ninetyeast Ridge. In von der Borch, C. C., Sclater, J. G., et al. (Eds.), Init. Repts. DSDP, 22: Washington (U.S. Govt. Printing Office), 477-483.

Wadia, D. N., 1961. Geology of India: London (Macmillan \& Co Ltd.), New York (St. Martin's press).

Zeitler, P. K., Johnson, N. M., Naeser, C. W. and Tahirkheli, A. K., 1982. Fission-track evidence for Quaternary uplift of the Nanga Parbat region, Pakistan. Nature, 298:255-257.

Date of initial receipt: 21 February 1989

Date of acceptance: 15 December 1989

Ms 116B-116 